Journal of Educational

and Psychological Sciences

Volume (6), Issue (6): 28 Feb 2022

P: 128 - 156

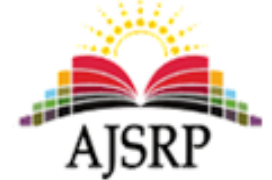

ISSN: 2522-3399
مجلة العلوم

التربوية والنفسية

المجلد (6)، العدد (6): 28 فبراير 2022 م

ص: 128 - 156

\title{
Psychological stress and its relationship to behavioral deviation in light of the Corona pandemic from the point of view of workers in government hospitals in Jordan
}

\author{
Reem Mahmoud Al-Rawashdeh \\ Ministry of Health || Jordan
}

\begin{abstract}
The aim of the research is to reveal the relationship between psychological stress and behavioral deviation in light of the Corona pandemic from the point of view of workers in government hospitals in Jordan. To achieve the objectives of the research and data collection, a questionnaire was used as a data collection tool, and the descriptive analytical correlative approach was used, and the study sample consisted of (294) male and female workers in government hospitals in Jordan. The results of the research showed that the level of psychological stress in light of the Corona pandemic from the point of view of workers in government hospitals in Jordan was average, and that the level of behavioral deviation from the point of view of workers in government hospitals in Jordan was also moderate, and the results also showed a positive correlation with statistical significance. Between psychological stress and behavioral deviation in light of the Corona pandemic from the point of view of workers in government hospitals in Jordan. And there were no differences in the perceptions of the study sample members towards the relationship of psychological stress in behavioral deviation due to demographic variables (sex, experience, and place of residence).
\end{abstract}

Based on these results, the researcher recommended the need for state agencies to study the precautionary measures they take due to the Corona pandemic before applying them, knowing their impact on members of society, relieving psychological pressures on them, and constantly evaluating those measures.

Keywords: Stress, Psychological, Behavioral Deviation, Corona.

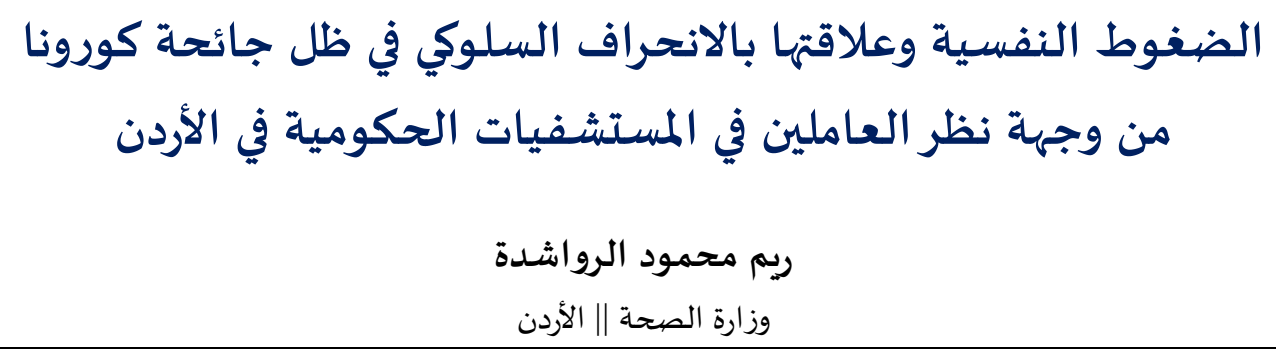

المستخلص: هدف البحث إلى الكشف عن العلاقة بين الضغوط النفسية والانحراف السلوكي في ظل جائحة كورونا من وجهة نظر

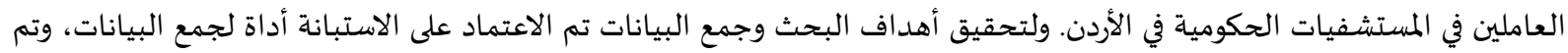

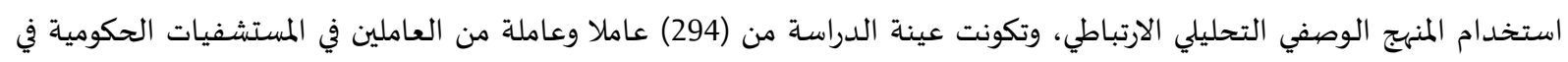
الأردن. وأظهرت نتائج البحث أن مستوى الضغوط النفسية في ظل جائحة كورونا من وجهة نظر العاملين في المستشفيات الحكومية في

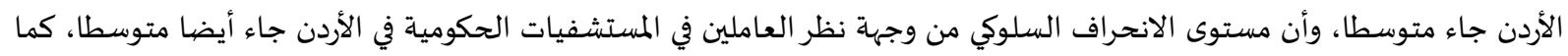

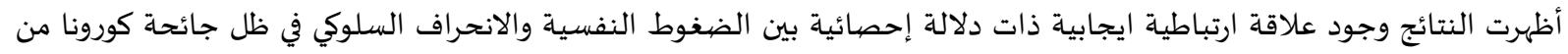

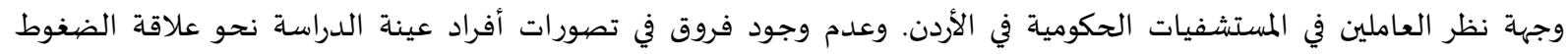




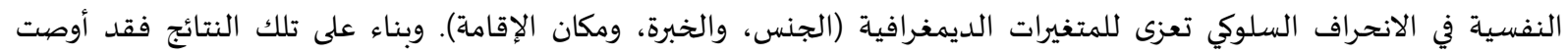

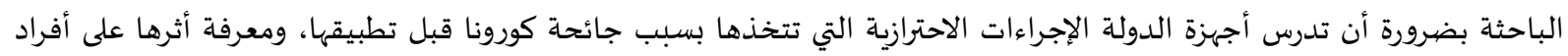

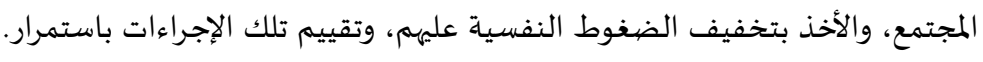

الكلمات المفتاحية: الضغوط، النفسية، الانحراف السلوكي، كورونا.

المقدمة.

يعد الانحراف ظاهرة اجتماعية خارجة عن معايير المجتمع وقيمه، وهي مشكلة اجتماعية تؤدي بسلامة

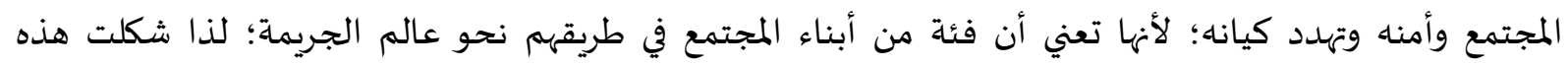

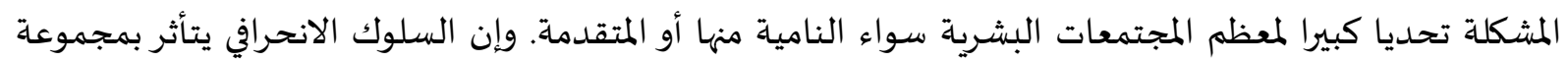

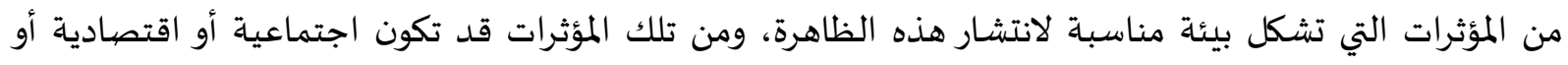

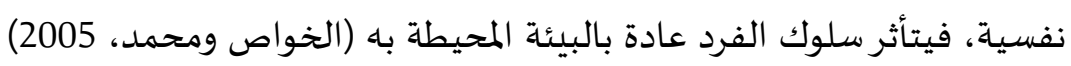
وقد شهدت المجتمعات مجموعة من المؤثرات التي غيرت في سلوك أفرادها وبالتالي في حياتهم، ولعل

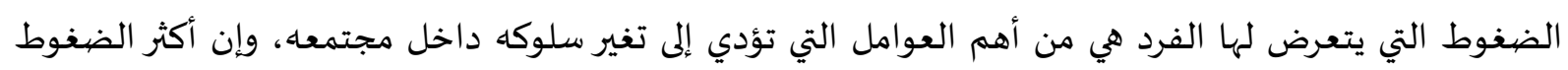

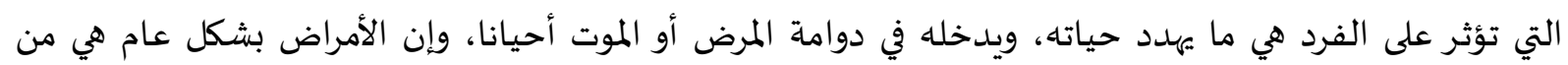

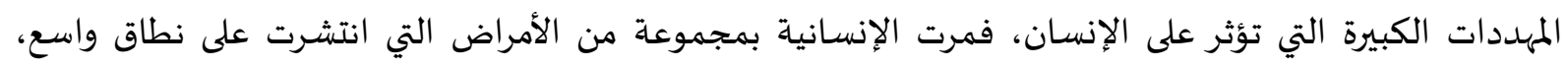
خاصة تلك الأمراض المعدية التي هددت حياة الإنسان بشكل مباشر (القحطاني، 2007).

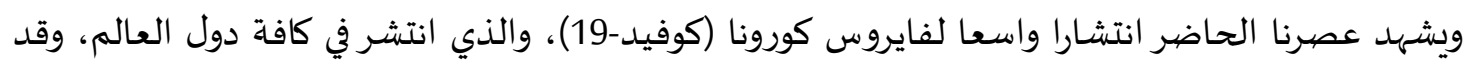

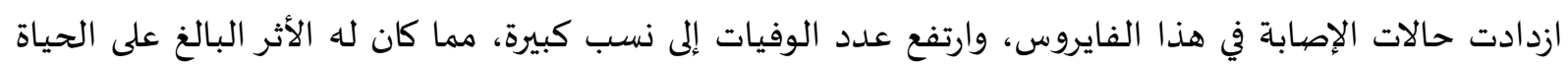

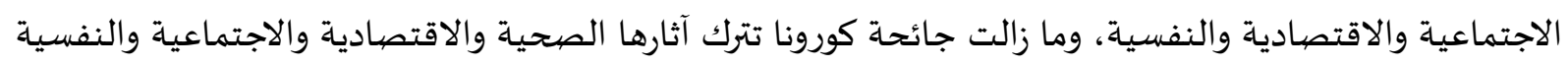
على العالم بطريقة كبيرة، ما تسبب في شلل وتعطيل مفاصل حياة الناس، ونتج عنها مهددات وآثار نفسياة، ومن أهم

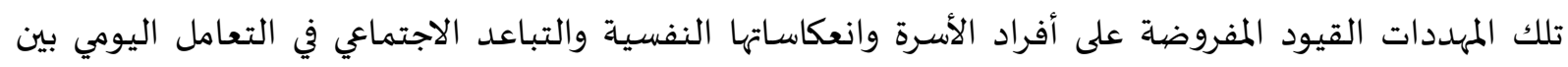

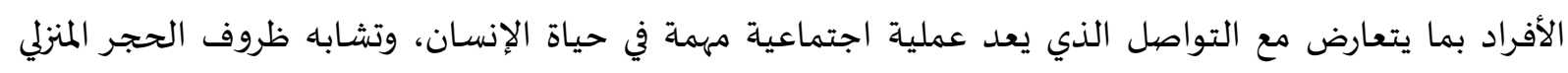

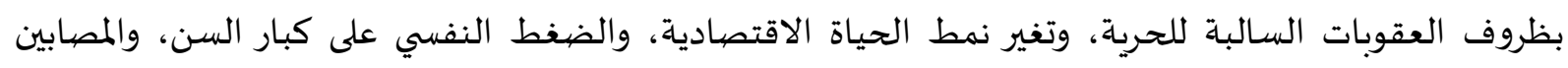
بالأمراض المزمنة (الشقير، 2020).

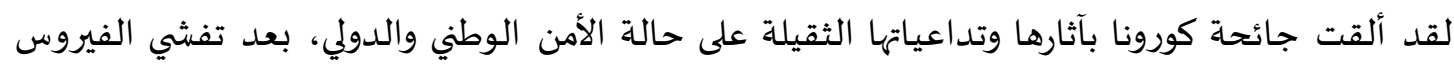

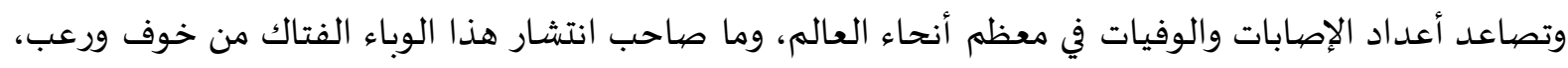

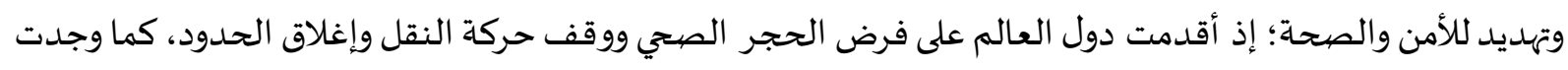

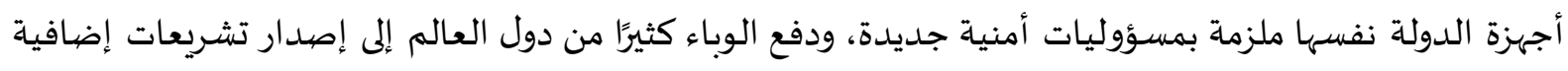

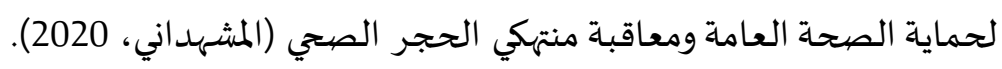
يتمثل تأثير الوباء على العلاقات والسلوكيات الاجتماعية في الدرجة الأولى بسبب التبدي التدابير العامة التي تتخذها

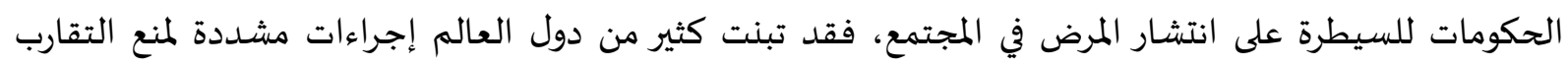

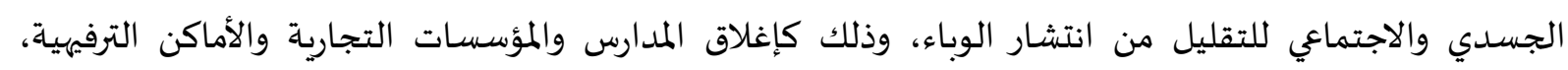

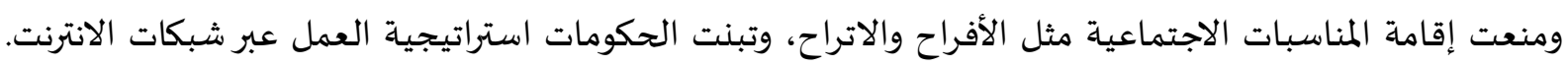

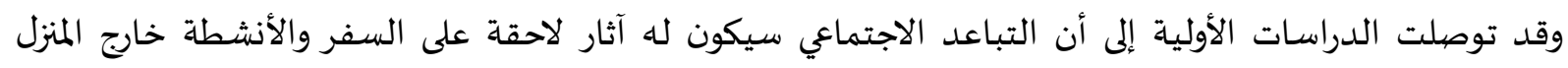
والتغيير في أنماط النقل العام والعزل الاجتماعي (Des Vos, 2020). 
لذا، جاءت هذه الدراسة لتتناول الضغوط النفسية التي تعرض لها المجتمع الأردني نتيجة انتشار فايروس كورونا، وعلاقة ذلك بالسلوك الانحرافي، وذلك من وجهة نظرعينة من العاملين في المستشفيات الحكومية في الأردن.

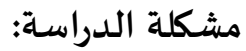

يشهد العالم تطورات متسارعة فيما يتعلق بجائحة فيروس كورونا وتأثيراتها الاجتماعية والاقتصادية، وأكدت

الإحصاءات اليومية التي تصدرها وزارة الصحة في الأردن أن عدد الإصابات بلغ (237.513) وذلك بتارئن

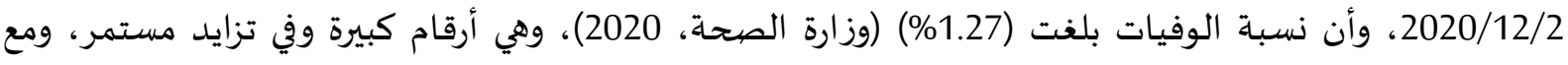

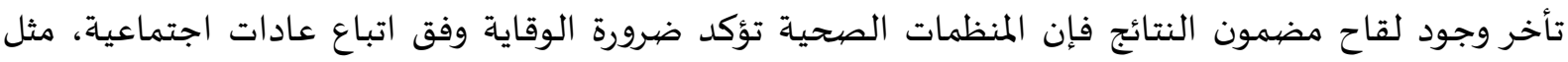

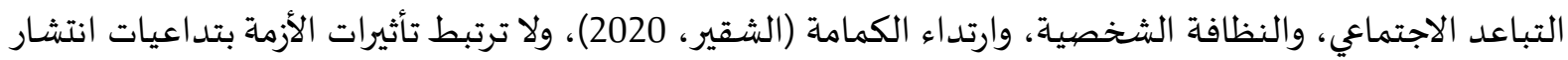

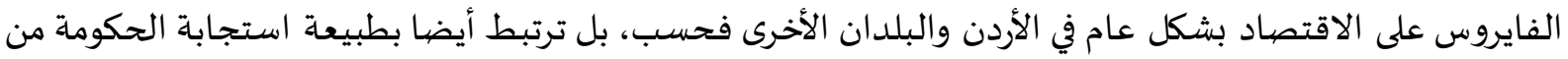

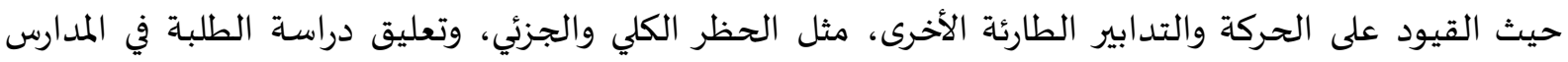

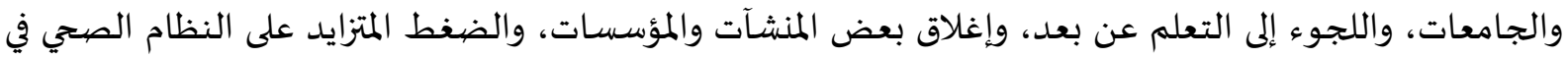

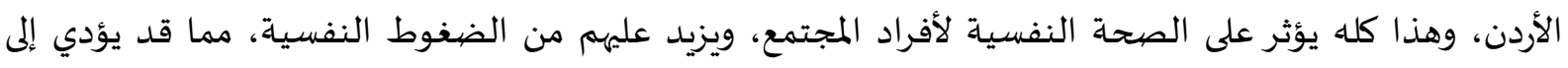
ظهور السلوك المنحرف لدى أفراد المجتمع، ويمكن تحديد مشكلة الدراسة بالسؤال الرئيس الآتي: ما علاقة الماته الضغوط النفسية بالانحراف السلوكي في ظل جائحة كورونا من وجهة نظر العاملين في المستشفيات الحكومية المانية

تسعى الدراسة للإجابة عن الأسئلة الآتية:

1- ما مستوى الضغوط النفسية في ظل جائحة كورونا من وجهة نظر العاملين في المستشفيات الحكومية في المئية

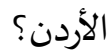

2- ما مستوى الميل للسلوك الانحرافي في ظل جائحة كورونا من وجهة نظر العاملين في المستشفيات الحكومية في

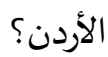

3- ما علاقة الضغوط النفسية بالميل للسلوك الانحرافي في ظل جائحة كورونا من وجهة نظر العاملين في

$$
\text { المستشفيات الحكومية في الأردن؟ }
$$

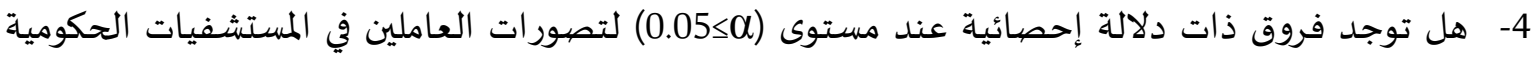
في الأردن نحو الضغوط النفسية وعلاقتها بالانحراف السلوكي في ظل جائحة كورونا وفقا للمتغيرات

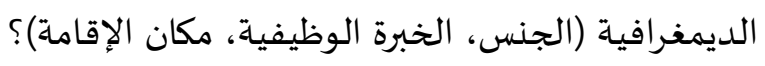

أهداف الدراسة

تسعى الدراسة إلى تحقيق الأهداف الآتية:

1- التعرف على الضغوط النفسية الناتجة عن انتشار فايروس كورونا من وجهة من وجهة نظر العاملين في الإنيه

$$
\text { المستشفيات الحكومية الأردنية. }
$$

2- التعرف على مستوى الانحراف السلوكي من وجهة نظر العاملين في المستشفيات الحكومية الأردنية.

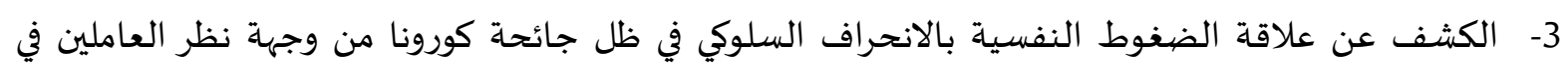
المستشفيات الحكومية الأردنية. 
4- تقصي الفروق في تصورات العاملين في المستشفيات الحكومية الأردنية نحو الضغوط النفسية وعلاقهها بالانحراف السلوكي في ظل جائحة كورونا وفقا للمتغيرات الديمغرافية (الجنس، الخبرة الوظيفية، مكان

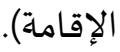

أهمية الدراسة

تأتي أهمية الدراسة من جانبين هما:

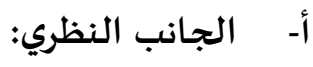

- أنها تعمل على سد النقص في الدراسات والأبحاث المتعلقة بموضوع الدراسـة.

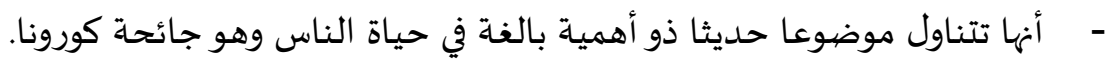

$$
\text { ب- الجانب التطبيقي: }
$$

- يؤمل أن تسهم الدراسة في توفير معلومات متخصصة في موضوع الضغوط النفسية، وعلاقتها بالانحراف

السلوكي في ظل جائحة كورونا.

- تقديم التوصيات التي تستند إلى النتائج العلمية لأصحاب القرار والمسؤولين عن جائحة كورونا في تبني

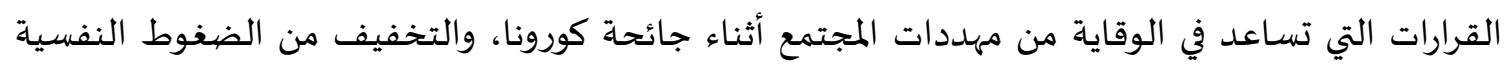
الناتجة عن ذلك.

حدود الدراسـة

اقتصرت الدراسة على الحدود الآتية:

الحد الموضوعي: علاقة الضغوط النفسية بالانحراف السلوكي في ظل جائحة كورونا.

الحدود البشرية: العاملون في المستشفيات الحكومية الأردنية.

الحدود المكانية: المستشفيات الحكومية في الأردن.

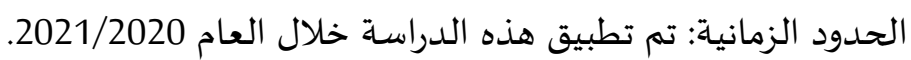

مصطلحات الدراسة وتعريفاتها الإجرائية

- الضغوط النفسية: تعرف الضغوط لغة "يقال ضغطه ضغطات أي طمره إلى شيء كحائط أو نحوه، وتعني كلمة

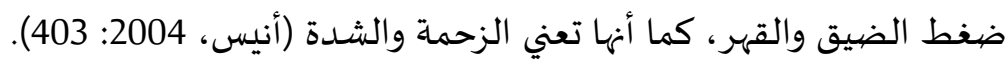

- أما اصطلاحا فهي "المثيرات أو التغييرات التي تحدث في البيئة الداخلية والخارجية للفرد وتكون شديدة واليدة ودائمة والتي تسبب للفرد عدم القدرة التكيفية، والتي تؤدي في ظروف معينة إلى الاختلال في السلوك أو الاختلال

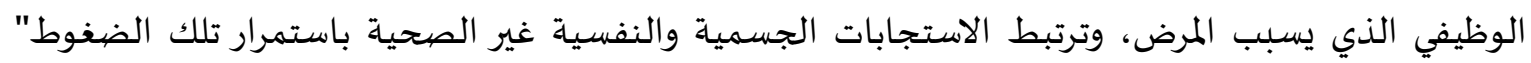

(السميران والمساعيد، 2014: 29).

O وتعرف إجرائيا بأها: الظروف أو المؤثرات التي يتعرض لها أفراد المجتمع الأردني والناتجة عن فايروس كورونا،

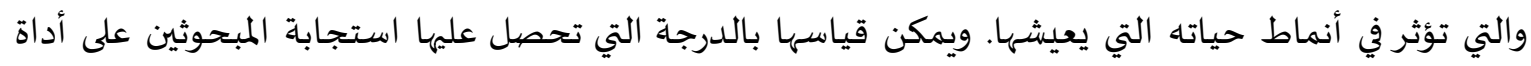

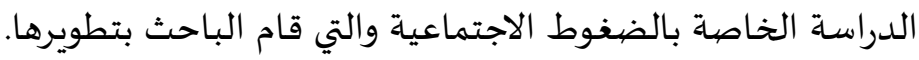

فايروس كورونا: هو "فايروس يسبب مرض كوفيد-19، وهو مرض معد يسببه آخر فيروس تم اكتشافه من

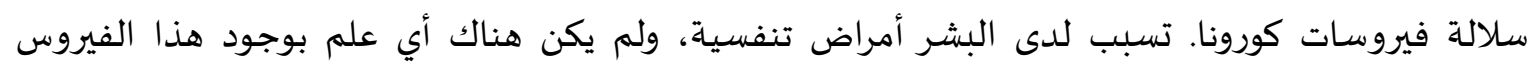


الجديد ومرضها قبل بدء تفشيه في مدينة ووهان الصينية في كانون الأول من عام 2019. وقد تحوّل كوفيد-19 الآن إلى جائحة تؤثر على العديد من بلدان العالم" (منظمة الصحة العالمية، 2020).

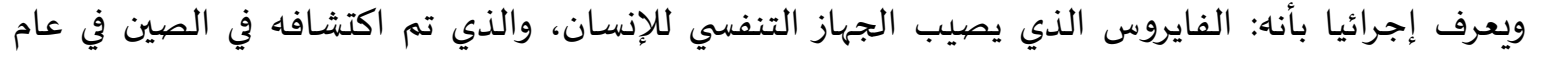

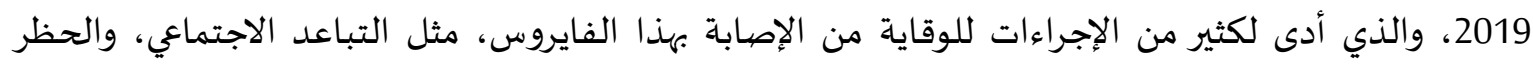

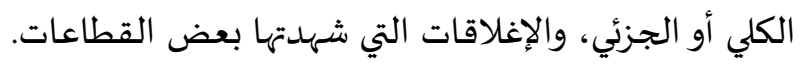

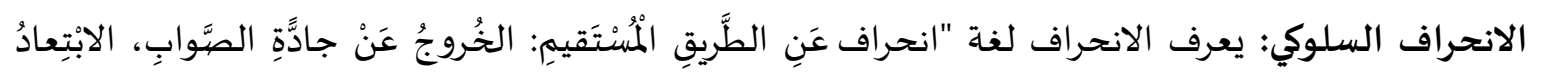

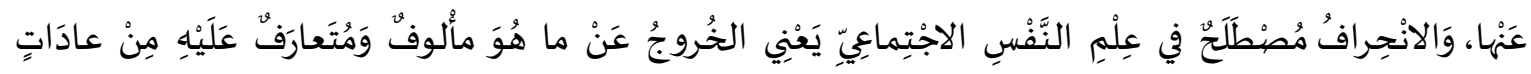

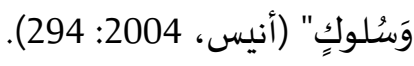
ويعرف اصطلاحا بأنه: "كل خروج على ما هو مألوف من السلوك الاجتماعي، دون أن يبلغ حد الإخلال الاجتماعي

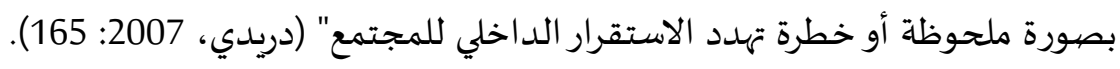

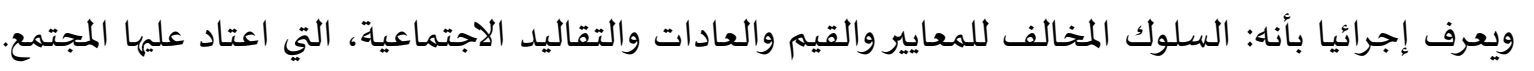

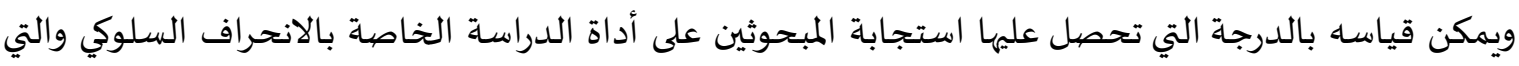
قام الباحث بتطويرها.

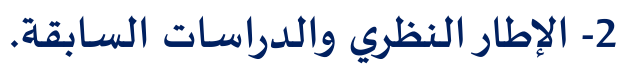
أولا - الإطار النظري.

الضغوط النفسية: - | (الضية

إن الضغوط ظاهرة إنسانية وجزء من نسيج الحياة عرفت منذ العصور القديمة ومتلازمة للإنسان وهى

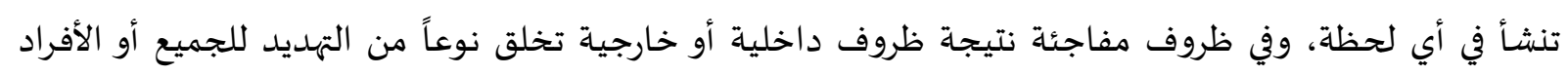

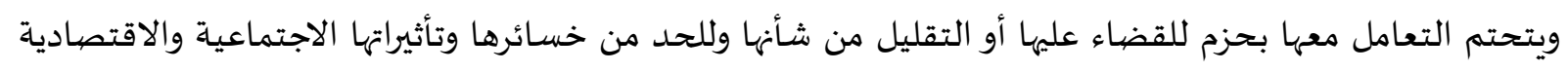

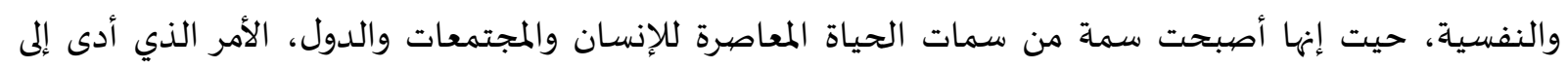

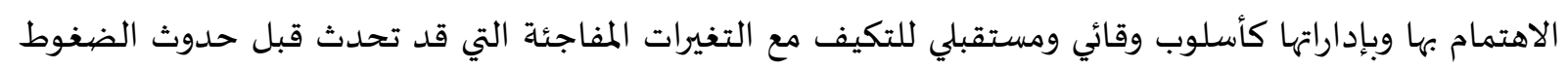

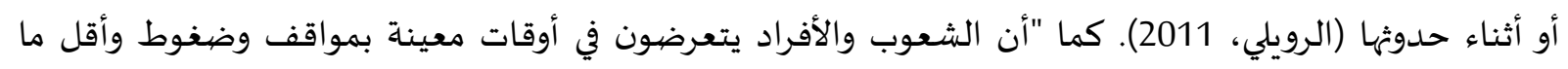

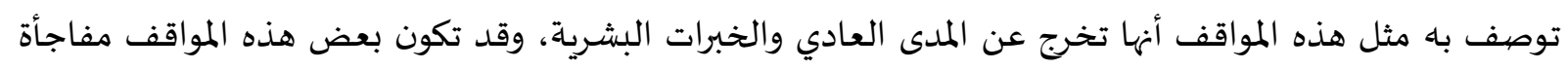

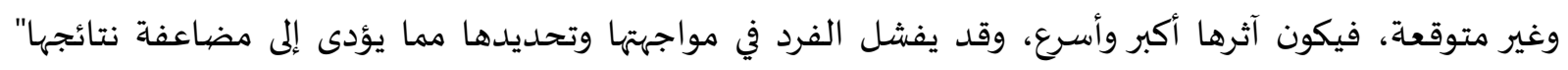

(عمر، 2016: 46)

والضغوط هي "الحالة التي يدركها الكائن الذي يتعرض لأحداث أو ظروف معينة بأنها غير مريحة أو مزعجة أو

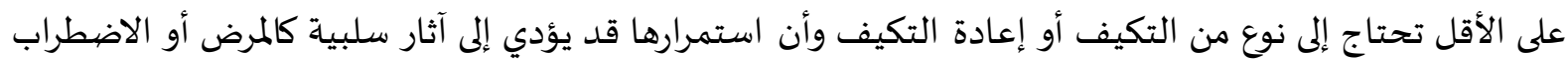

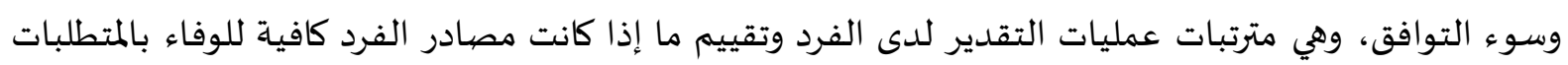

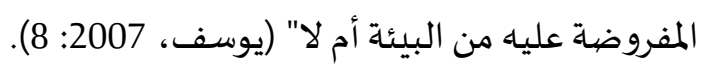

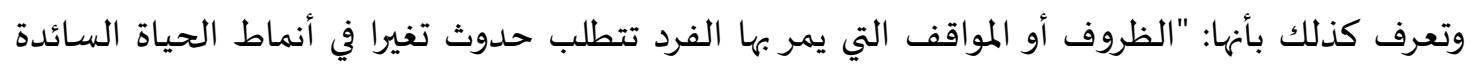

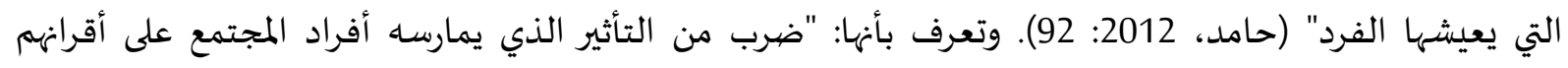

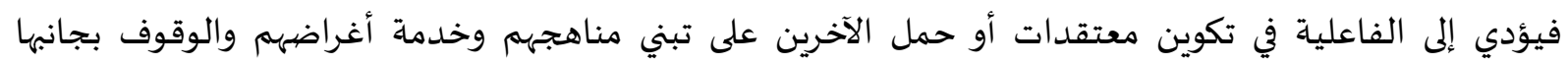

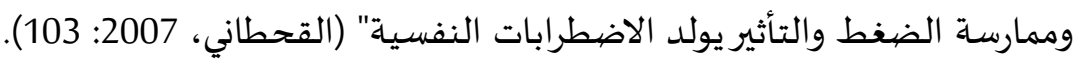


وتعرف الضغوط النفسية بأهها: "ضرب من التأثير الذي يمارسه أفراد المجتمع على أقرانهم فيؤدي إلى الفاعلية في تكوين معتقدات أو حمل الآخرين على تبني مناهجهم وخدمة أغراضها والوقوف بجانها وممارسة الضغط

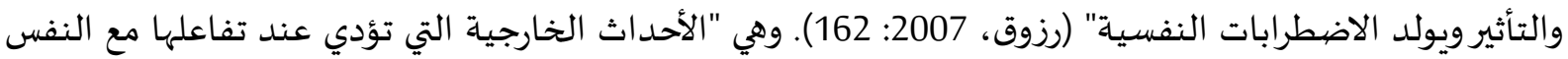

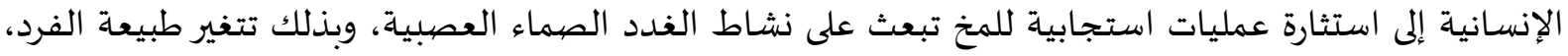
فهي أحداث نفسية أو اجتماعية تسبب اضطرابات نفسية" (العيسوي، 2006: 17).

ثالثا: العوامل الدافعة للضغوط النفسية تنشأ الضغوط عندما يدرك الفرد عدم قدرته على التوازن بين متطلبات الحياة وقدرته على الاستجابة لها،

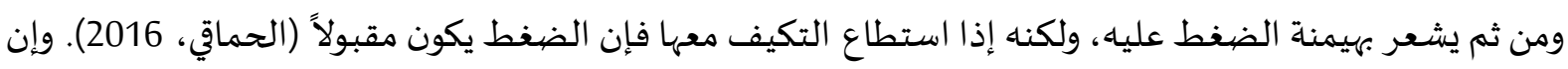
"الضغوط تزداد بزيادة الالتزامات العائلية وظروف الأسرة التي قد لا يستطيع أن يتحملها الفرد مما يترتب عليها زيادة المعاناة والضغوط (الطريري، 2004)." "وهناك مجموعة من العوامل التي تؤدي إلى نشوء الضغوط الاجتماعية، والتي ذكرها السميران والمسساعيد (2014) ) وهي على النحو الآتي: 1. البيئة الاجتماعية: هي مجموعة العادات والتقاليد والقيم والثقافات المحلية والاتجاهات، حيث تأثر تلك البيئة على مدى فهم واستيعاب الأفراد لمجريات الأحداث داخل المجتمع، ومن ثم على سلوكياتهم وتصرفاتهم (غريب، 2006). وحيث يلعب الوسط الاجتماعي دورا هاما في صياغة سلوك الفرد وشخصيته، وإنتاج البيئة الغنية ليس كإنتاج البيئة الفقيرة.

والبيئة الاجتماعية هي تلك الصيفة الحياتية والعلاقات الإنسانية المختلفة التي تتكون نتيجة التفاعل والتعامل الإنساني القائم بين الأفراد وهذه الوضعية الاجتماعية تؤثر بلا شك في أفرادها القادمين إلها بعد الولادة، وهي غالبا ما تطبعهم بطابعها وتمنحهم صفاتها وحينما نتكلم على البيئة الاجتماعية للطفل نقصيد بها الأجواء

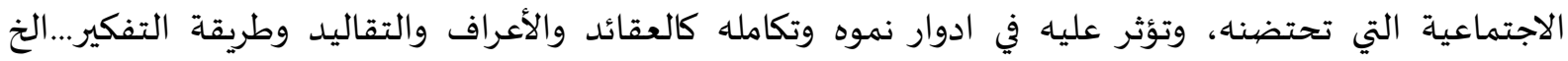

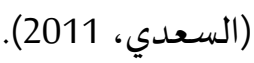
2. أسباب حضارية وثقافية: إن الاتجاهات الثقافية والحضارية للمجتمع تؤثر في انتاج السلوك المضطرب، وقد

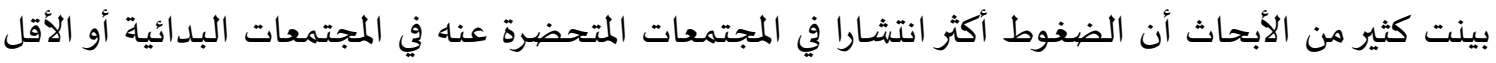
تحضرا. والوسط الثقافي الذي يعيش فيه الفرد هو الذي ينمي السلوكات الاجتماعية لدياه، ففي المواقف الاجتماعية يعيش الفرد عناصر الثقافة ويمارسها، وهذا ما يسمى بعملية التعلم الاجتماعي أو التنشئة

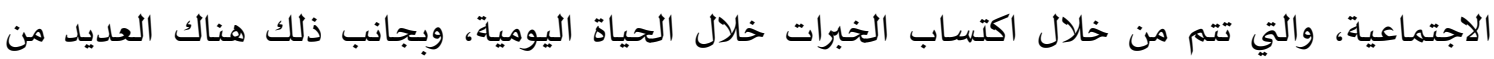

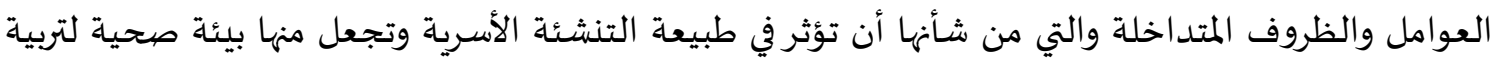

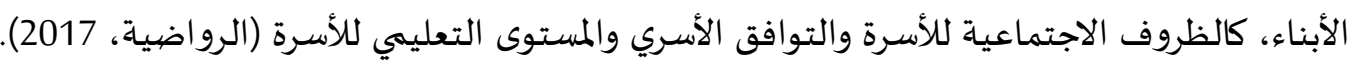

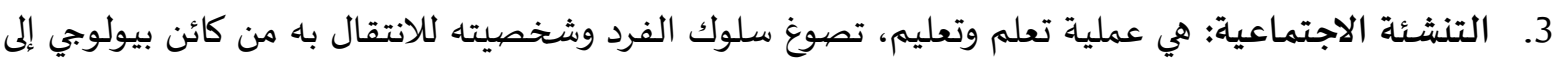

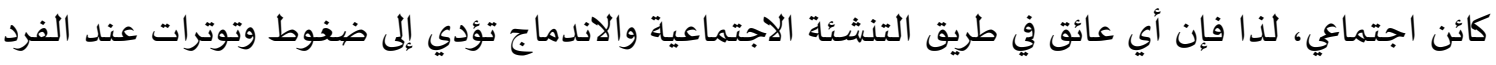

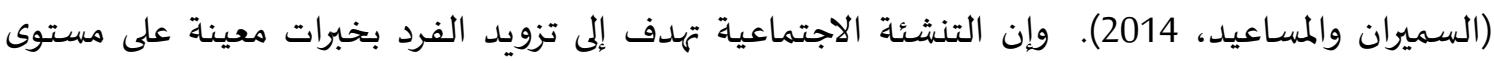

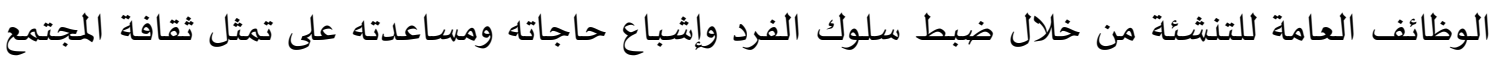

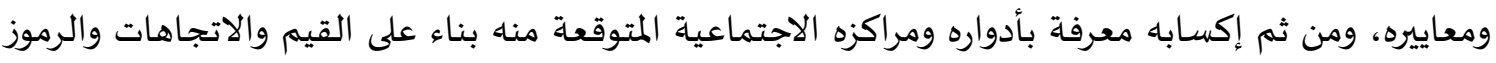

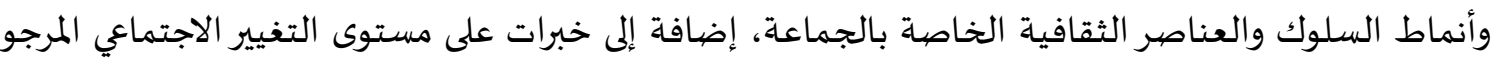


الوصول إليه في مجتمع معين من خلال مراقبة الاتجاهات والنزاعات والظواهر سواء القديمة أو المستجدة في

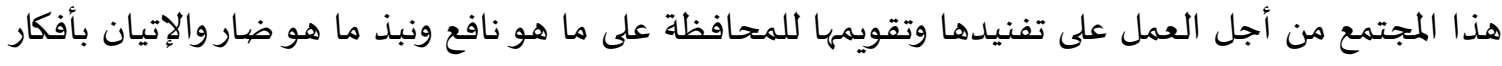
مبتكرة وفق حاجة المجتمع الإنسانية (العابد، 2010).

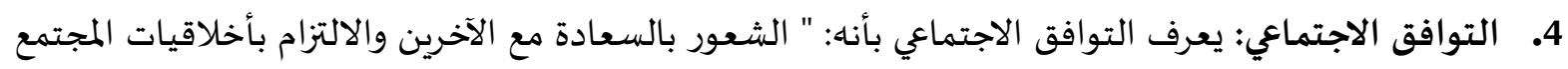

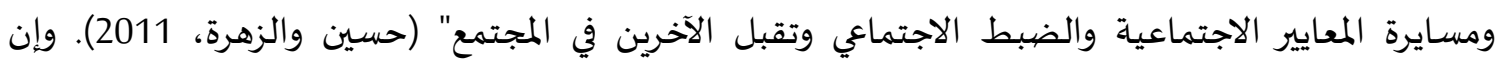

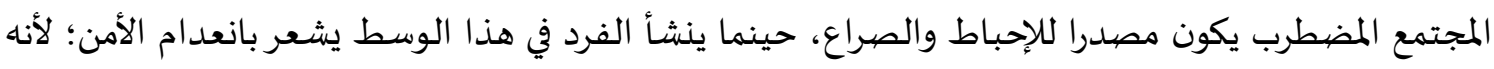

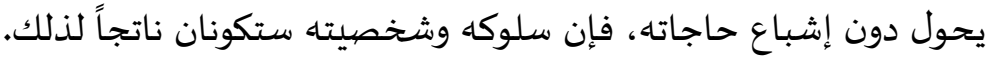

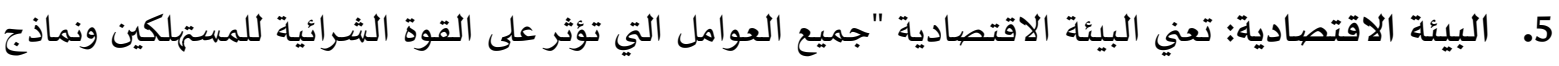

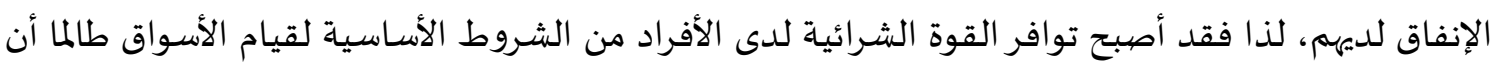

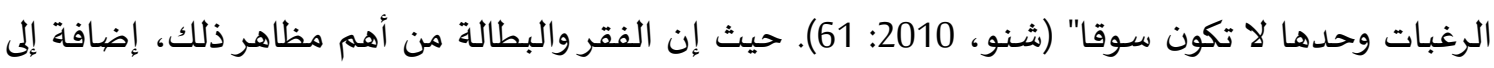

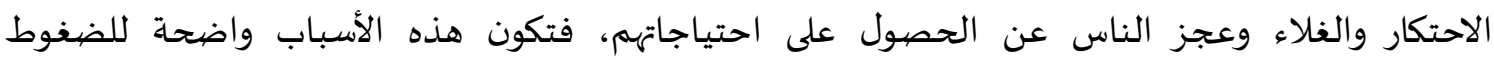
الاجتماعية عند الجماعات والأفراد.

السلوك الانحرافي

أولا: مفهوم السلوك الانحرافي "تعد الانحرافات السلوكية أحد الجوانب السلبية التي تشوه بناء المجتمع، وتفقده قيماه وقواعده الثابتة

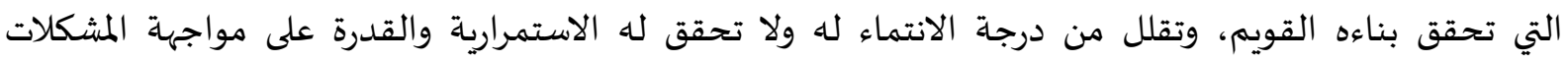

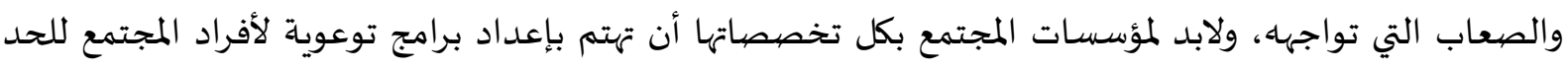

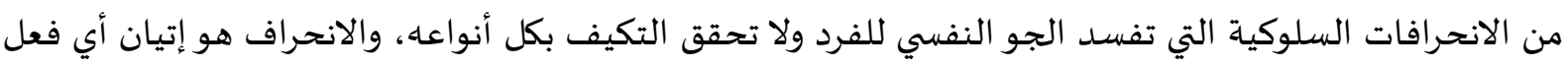

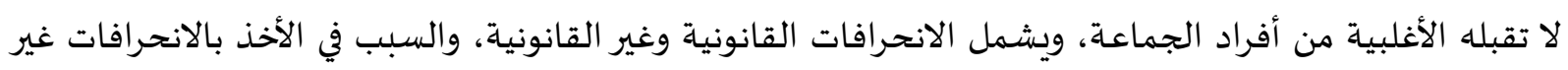

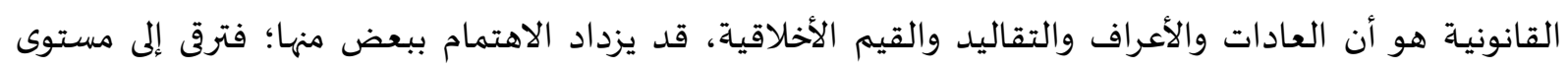

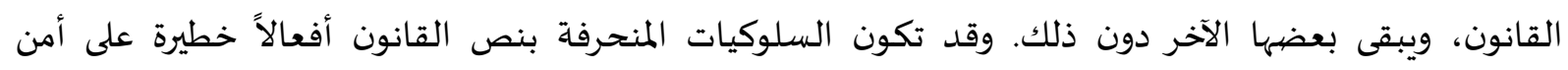

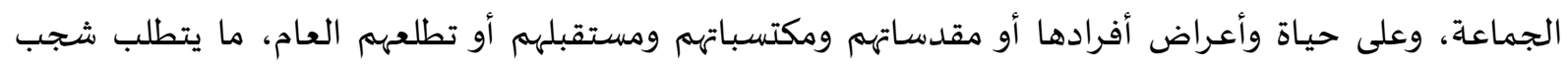

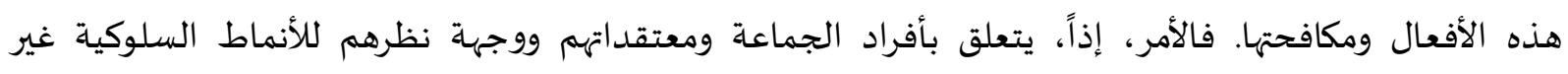

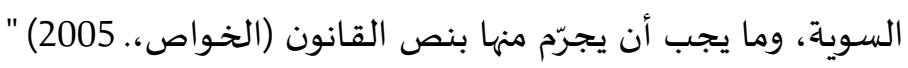

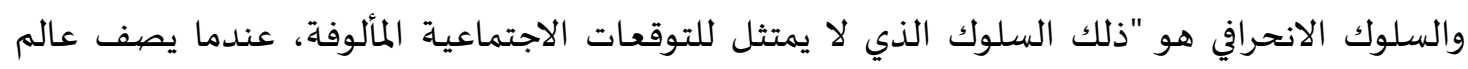

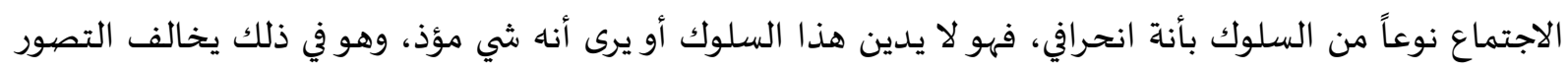

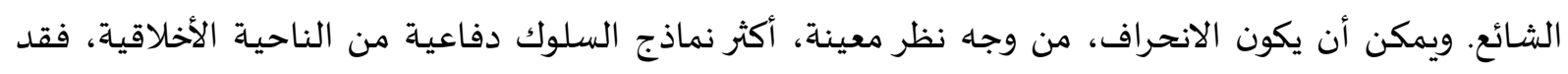

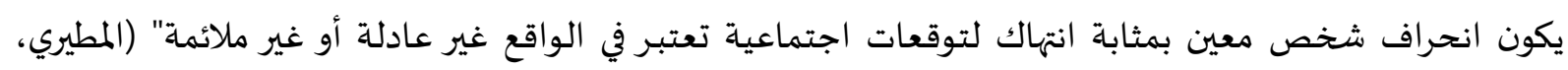

والانحرافات هي "كل سلوك سيء يقوم باه الفرد يتعارض مع المعايير الاجتماعية التي تعارف عليها غالبية

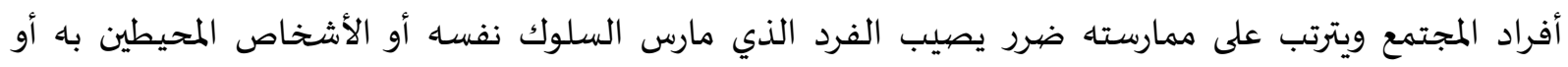
المجتمع بصفة عامة" (عبد الجواد، 2014: 38). ويعرف من الناحية النفسية بأنه: "عرض من أعراض عدم التكيف التهديف نتيجة قيام عقبات مادية أو نفسية

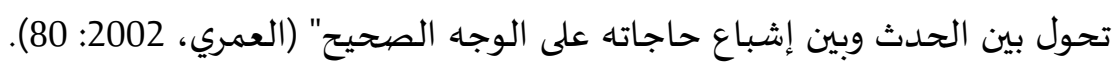


من خلال ما ورد من تعريفات سابقة يظهر أن الانحراف السلوكي هو الخروج عن المعايير الاجتماعية

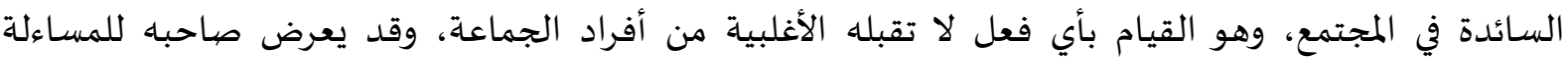
القانونية والمحاكمة.

ثانيا: العوامل المؤدية للانحراف

تنقسم العوامل المؤدية للانحراف إلى قسمين: عوامل داخلية وعوامل خارجية، وهي على النحو الآتي: "

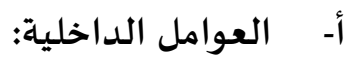

1. العوامل النفسية: حيث إن القلق والاكتئاب والوحدة النفسية والانطواء والشعور بالنقص والتوتر وصعوبة

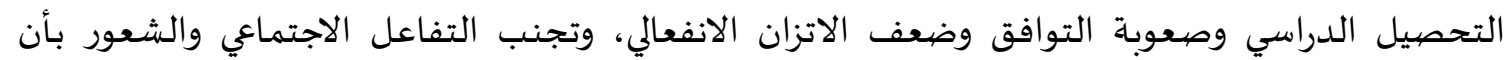

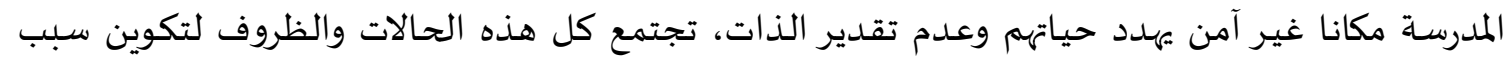

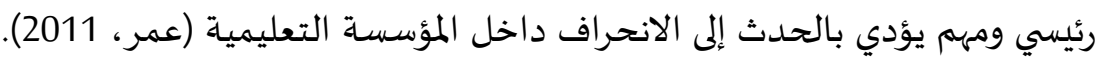

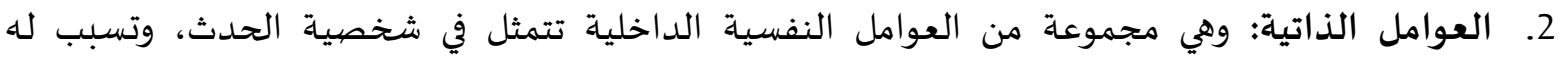
اضطرابا نفسيا وعصبيا وجسديا، ومنها: الوراثة التي تساعد على نشوء الاستعداد للانحراف، وأن للبيئة

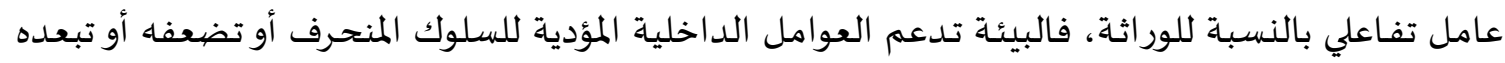
(جعفر، 2004). ولتدني مفهوم الذات دورا كبيرا كأحد العوامل الذاتية المؤدية للانحراف فتشوهوه مفهوم

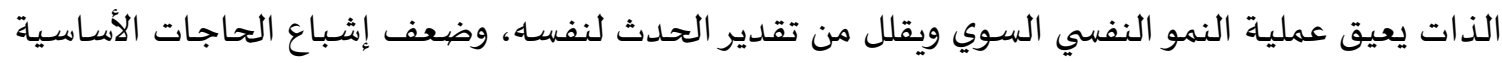

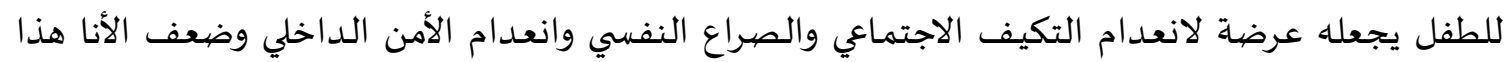
يجعل الفرد متجها للانحراف محاولا التوافق النفسي. لالعيل ب- العوامل الخارجية وتتمثل في: ضعف الانضباط وغياب القدوة الحسنة وقلة التقيد بالقوانين وغياب اتخاذ

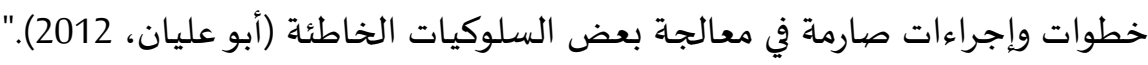

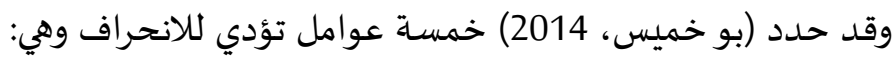

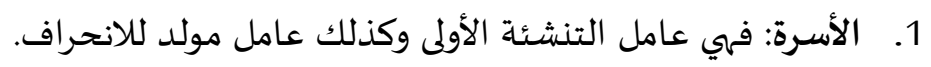
2. المدرسة: وتلعب دورا هاما بعد الأسرة في تعلم الطفل بعض القواعد وتهل وتقترح عليه بعض النماذج التي

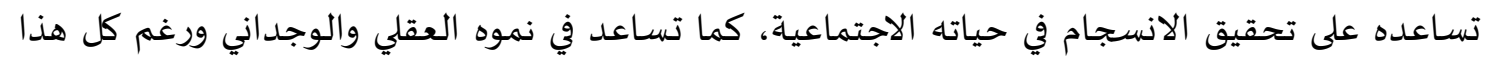

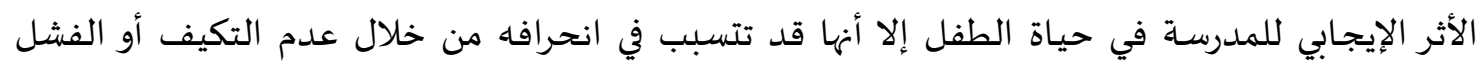
الدراسي. 3. العمل: ربط العلماء سن دخول سوق العمل بالانحراف فكلما كان دخولهم في سن مبكرة كلما زادت فرصة الانحراف.

4. الأصيدقاء أو الرفاق: وجود الشخص بين جماعة الأصدقاء يحدث تأثيرا متبادلا فكل منهم يؤثر في شخصية

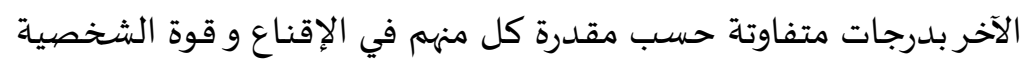

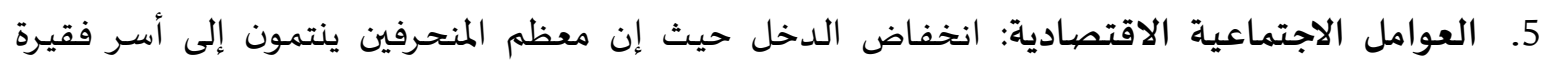
ويشغل آباؤهم وظائف دنيا، كما إن التنوع الثقافي وطبيعة أنماط العلاقات التات الاجتماعية تؤثر على الانحراف. 
ثالثا: النظريات المفسرة للسلوك الانحرافي

قدم علم الجريمة العديد من التفسيرات السوسيولوجية للسلوك المنحرف، التي تبلورت فيما بعد على

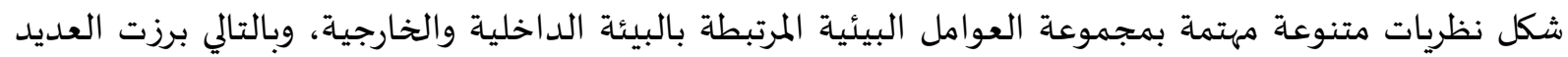
من التفسيرات النظرية للسلوك المنحرف، ومن النظريات التي تفسر السلوك المنحرف ما يلي:

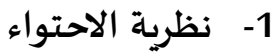

تركز نظرية الاحتواء على التضامن الاجتماعي في الضبط الاجتماعي، وأن هناك العديد من العوامل الاجتماعية والنفسية التي تشكل قوة دافعة للسلوك الإنساني، حيث لم تغفل نظرية الاحتواء عن المتغيرات النفسية

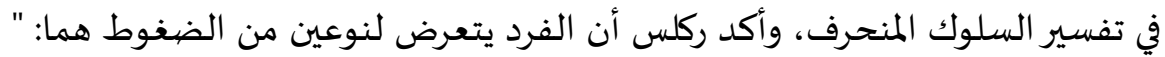

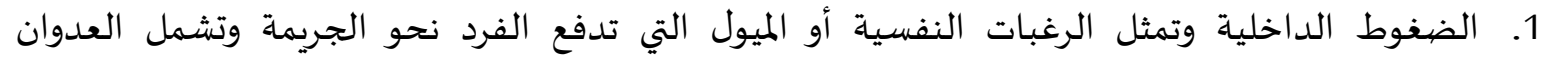
والإحباط والغضب والتوتر والثورة والصراع العقلي والحاجة إلى الإشباع الآني.

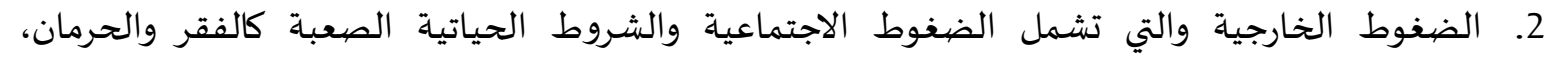

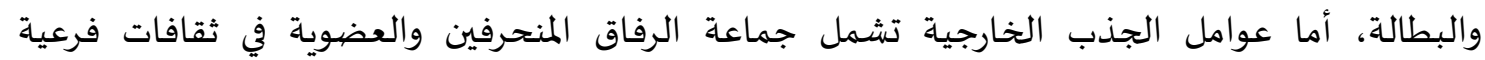

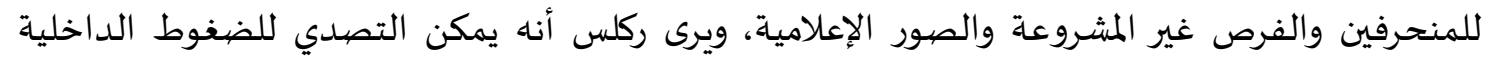
والخارجية وعوامل الجذب الخارجية والداخلية عن طريق الاحتواءات الداخلية والخارجية، وأن الأطفال

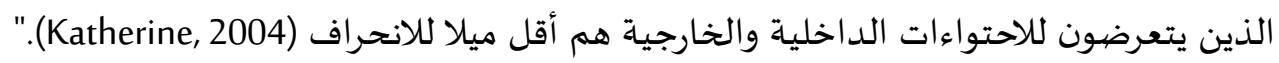
وتعد نظرية الاحتواء من النظريات التكاملية التي اهتمت بدراسـة الفرد في المجالين السيكولوجي النفسي، والسوسيولوجي الاجتماعي (الوريكات، 2004).

وركز ركلس من خلال نظريته كما يشير (الوريكات والمجالي، 2014) على نوعين من الاحتواء، هما:

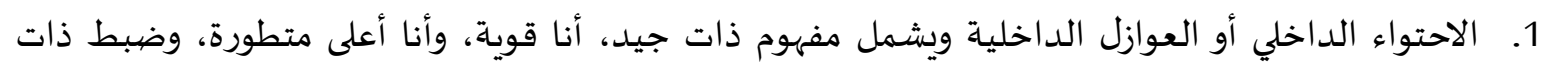

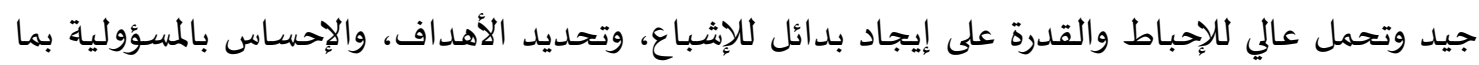
يطور الإحساس الموجب بالذات والالتزام بالقيم أو القوانين.

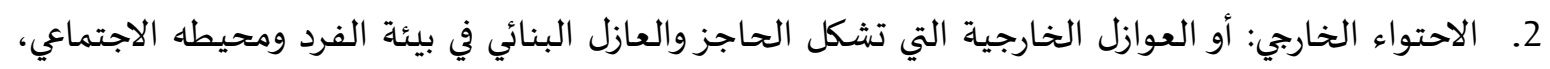

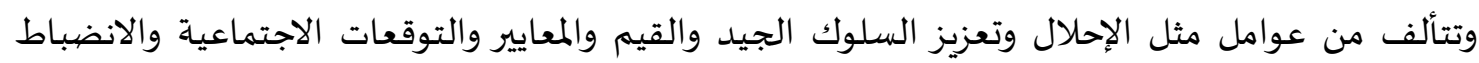

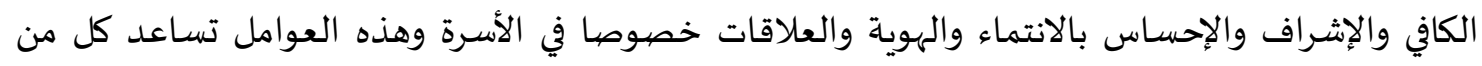

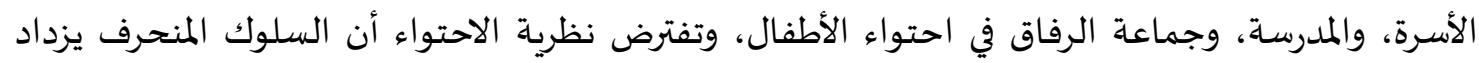

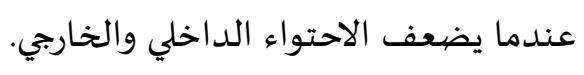
2- 2 - 2 نظرية التحليل النفسي

وضيع هذهِ النظرية سيجموند فرويد، وهو مؤسس مدرسة التحليل النفسي في علم النفس، ووفقاً لهذهِ

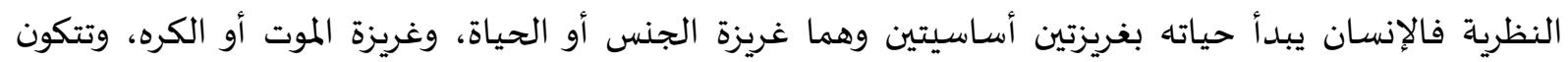

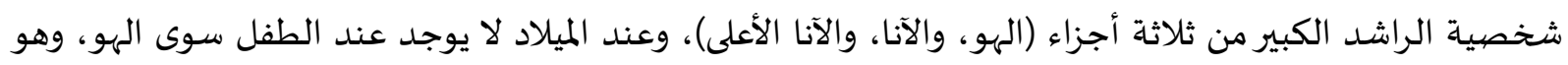

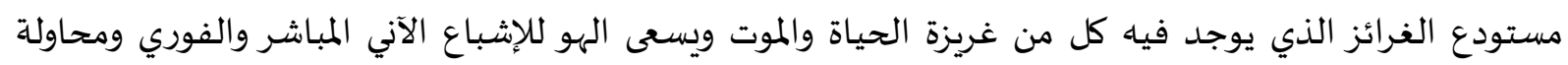

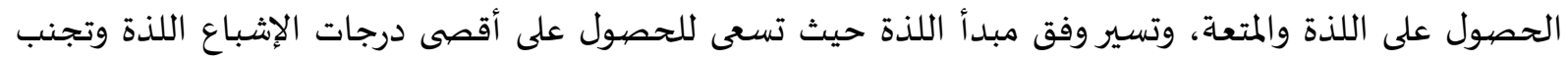

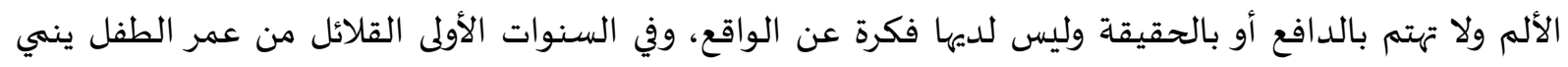

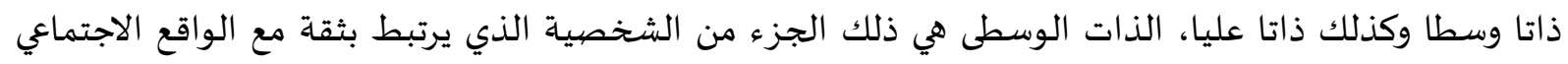

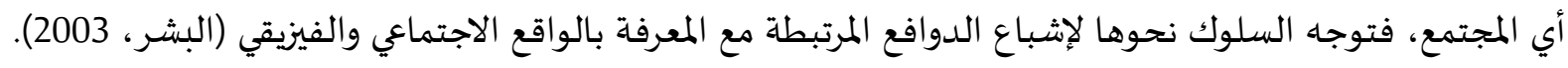


وتظهر الأخلاقيات مع الشعور بالذنب ومع ظهور الذات الوسطى، وهي القوة الرئيسية الناتجة عن عملية التنشئة الاجتماعية للفرد حيث تقوم مقام الضمير الخلقي الذي يقوم في الإنسان بوظيفتين وهما: وظيفة الردع

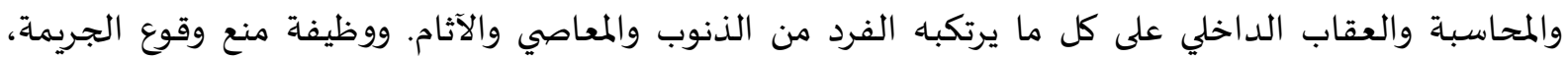

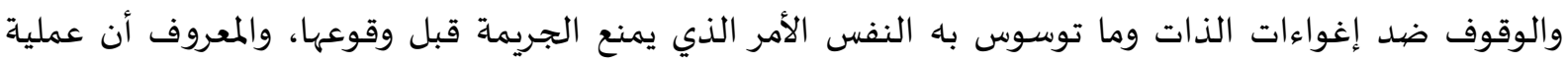
التنشئة الاجتماعية هي العملية التي يكتسب الفرد من خلالها قيم المجتمع ومعايره وأنماطه وسلوكياته المقبولة

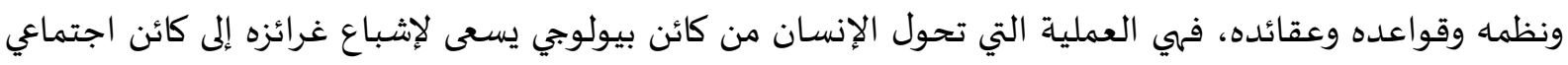

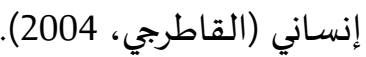

كما تقدم النظرية التحليلية تفسير لانحراف الأحداث، كونه ناتج من شخصية سيكوبائية تمتاز بعدة خصائص منها، الميل للعدوان، الكذب، عدم الشعور بالذنب، ضعف الضمير الخلقي، عدم الاستفادة من وسائل النصح والعقاب، الأنانية المفرطة والرغبة في العدوانية، والميل إلى الاستحواذية (العيسوي، 2001). وتنتج مثل هذهاه

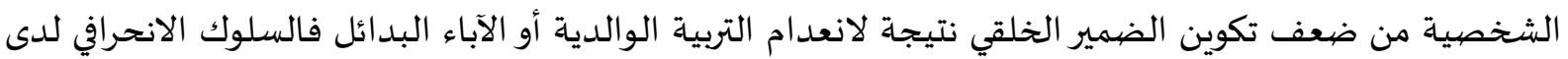

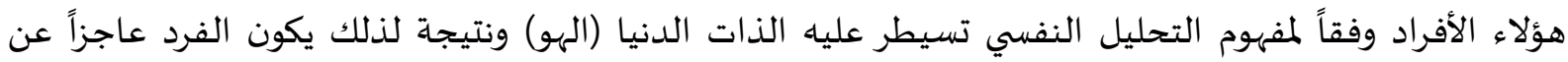
السيطرة على البواعث الإجرامية

جائحة كورونا

أولا: ظهور فيروس كورونا في 12/31 2019 تم إبلاغ المكتب الإقليمي لمنظمة الصحة العالمية في الصين بحالات الالتهاب الرئوي المسبب لمرض غير معروف تم اكتشافه في مدينة ووهان بمقاطعة هوبي الصينية، وتم إعلان فيروس كورونا المستجد المعروف

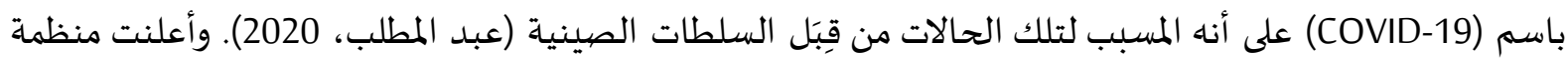

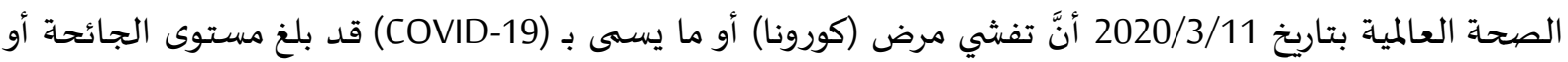

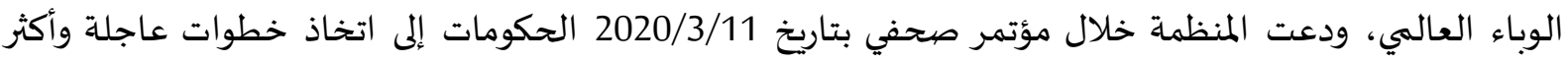

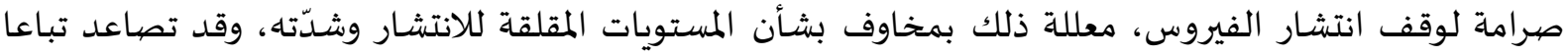

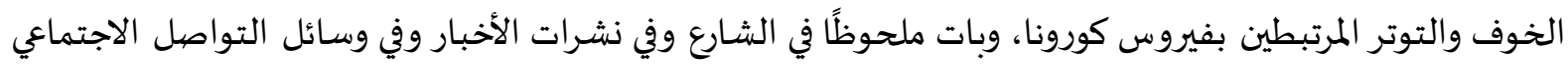
والمحادثات الجماعية؛ حيث إن الكثيرين قلقون وعاجزون عن استيعاب ذلك التزايد المتسارع في أعداد المصابين بالمرض

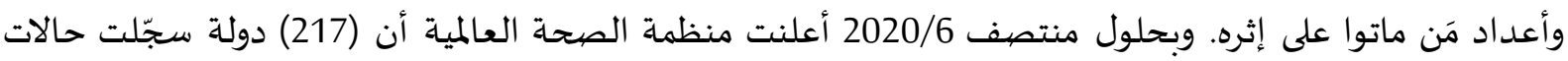

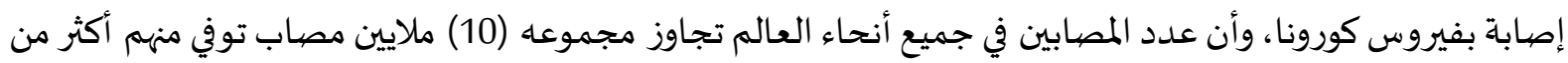

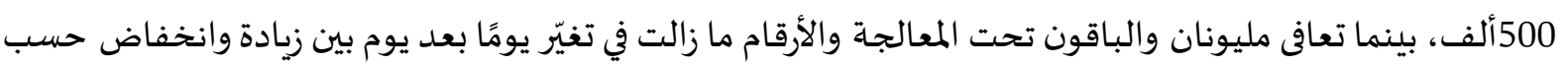
الدول (المشهداني، 2020).

ثانيا: الآثار الاجتماعية والاقتصيادية لجائحة كورنا

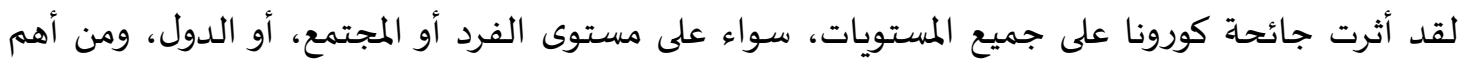

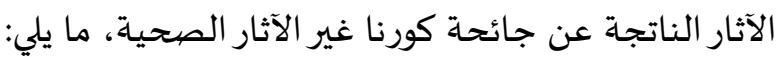

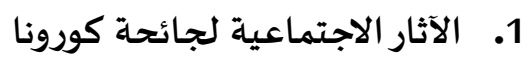
يواجه العالم أزمة إنسانية تعد من أكبر الأزمات التي تهدد استقراره وتقوض ترابطه وهو وباء كورونا، الذي

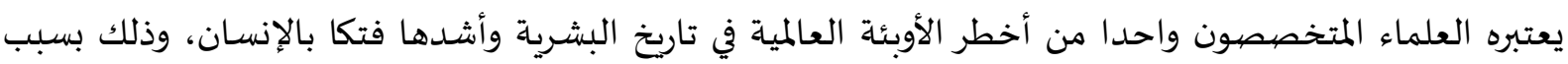


انتشاره طبقيا ومناطقيا في ظل غياب دواء ناجع لمقاومته والقضاء عليه،، ومع اختراق الفيروس جميع دول العالم

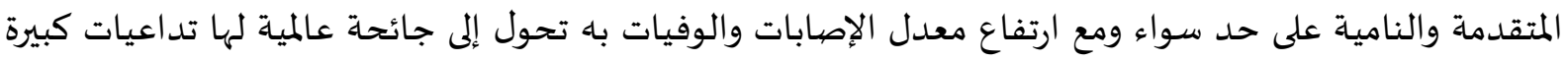
في المنومة الأخلاقية على المستوى الفردي والمجتمعي والدولي (غازي، 2020).

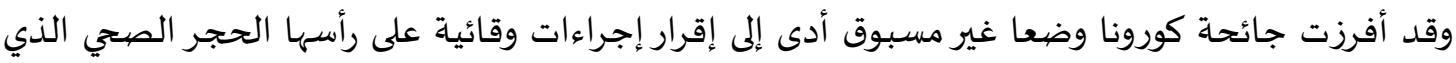

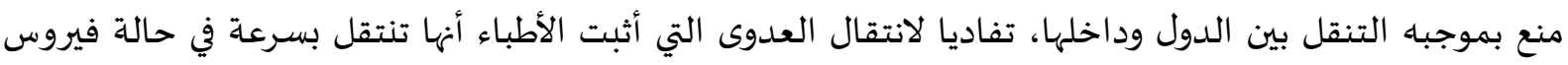

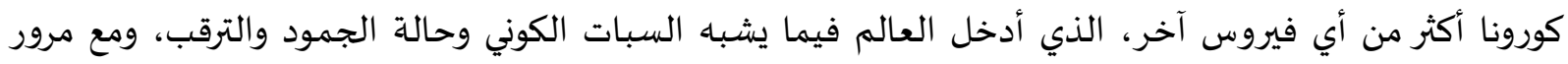
الوقت أفرز الخوف من الفيروس تخوفات أخرى على مستويات عدة، فتوقف الاقتصاد كان من بين نتائجه تأثر

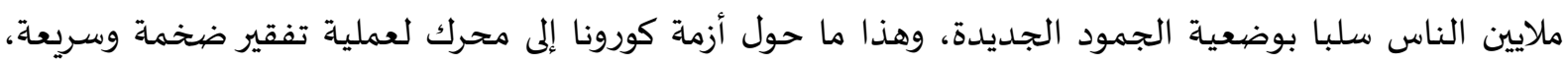

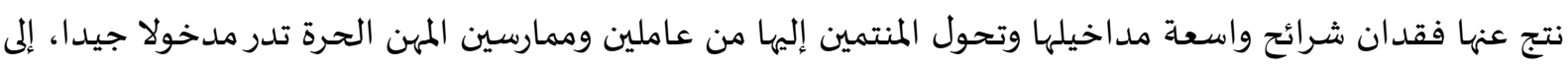

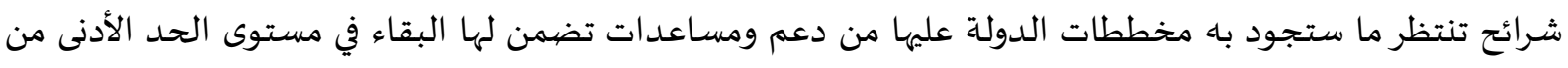
العيش (الحاجي، 2020).

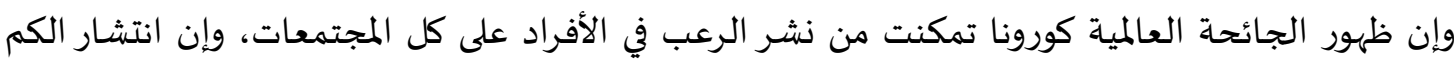

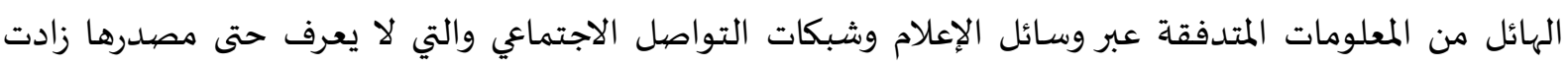

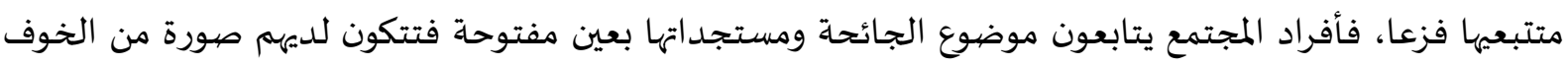

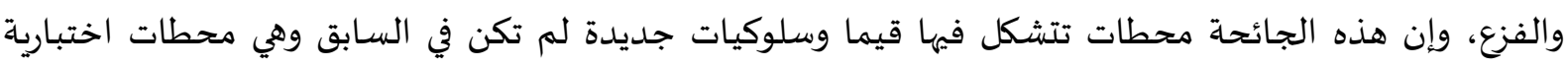

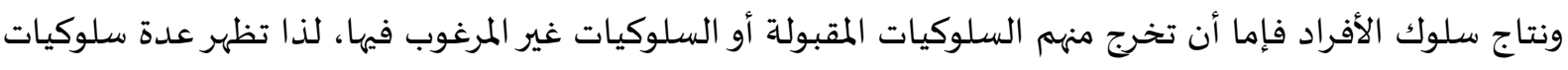

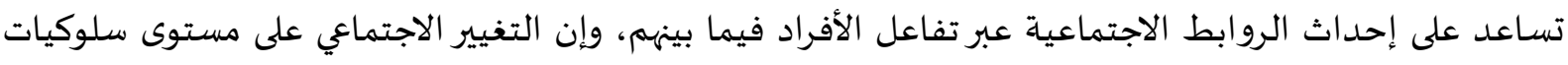

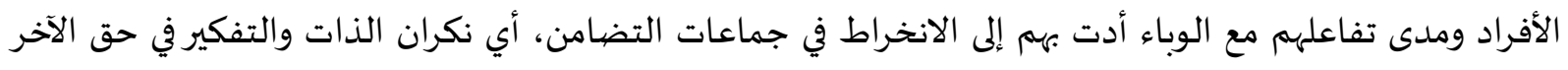

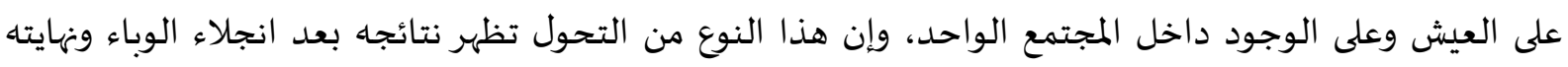
(كسور، 2020).

وقد وضعت القيم الأخلاقية أمام اختبار جديد، إذ بات المجتمع البشري يشهد حالة من القلق المعنوي،

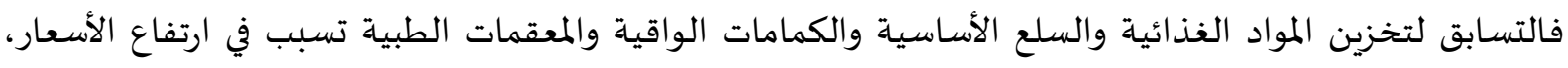
وإذا استمر الوضع فسووف يحرم أفراد المجتمع غير القادرين على الحصول على هذه السلع السلع وهو ما يخلق شعورا

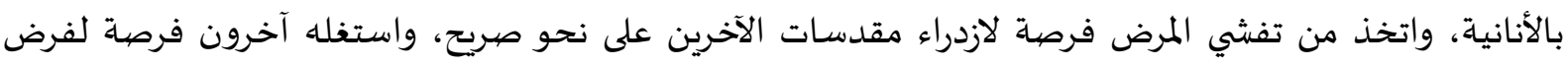

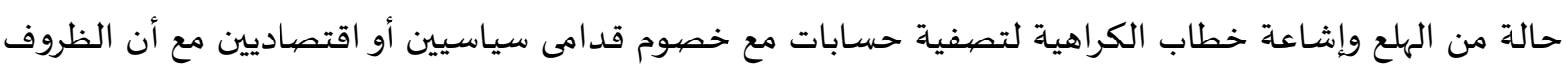
تقتضي التكاتف الإنساني (غازي، 2020). وقد تسببت جائحة كورونا بازدياد الخلافات الأسرية وارتفاع نسب الطلاق في العديد من الدانداند الدول، فقد

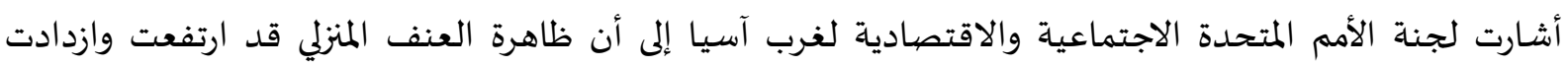

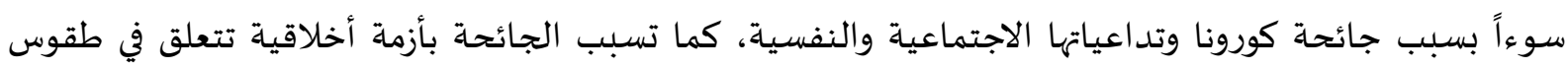

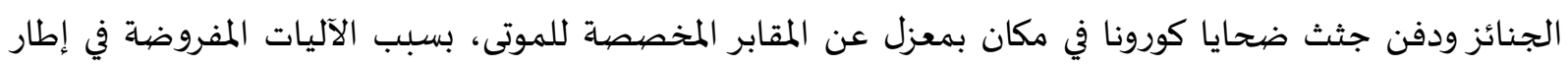
الرقابة الاجتماعية (قادة، 2020). وإن جائحة كورونا فرضت على كل المجتمعات في العالم الحجر المنزلي، الأمر الذي جعلهم يلزمون بيوتهه

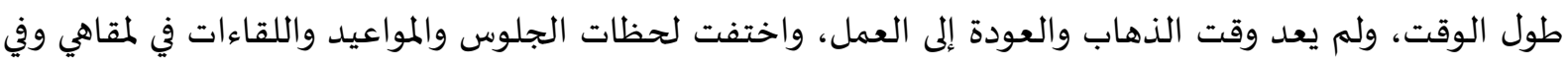
مقرات العمل، فقد اختفى الفضياء الواسع للشارع أو الحديقة أو المقهى، لصالح البيت والمأوى الذي ولفي يعود إليه 
الإنسان مساء كل يوم، ومع الحجر وتبعاته يعود الإنسان إلى ذاته طالبا النجاة له ولأهله ولأقاربه، وفي الوقت ذاته

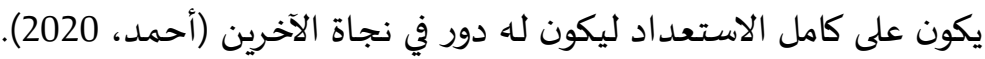

2. الآثار الاقتصادية لجائحة كورونا

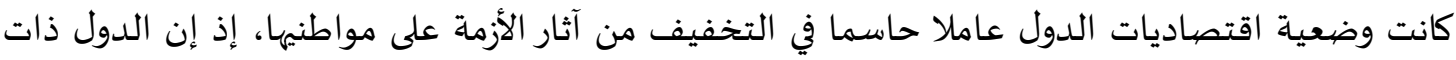
الاقتصادات القوية قدمت مساعدات مالية كبيرة للأسر المتضررة لمساعدتها على ضمان الحد الأدنى من حاجياتها، والحفاظ على مستوى أدنى من الاستهلاك يجنب الدورة الاقتصادية الشلل التام، مما قد يحول الأزمة من اقتصادية

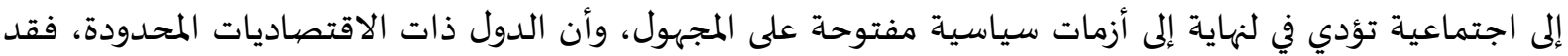
حاولت بسرعة التدخل للتخفيف من حدة التداعيات السلبية للأزمة الاقتصادية، لكن ذلك التدخل كان محدودا ومرتبطا بفترة معينة فرضت الدول فيها على الناس عدم العمل والالتزام بالحجر الصحي تفاديا لانتشار العدوى، وبقدر ما كان تدخل الدول غير كاف عموما لجميع الفئات المتضررة على غرار الدول ذات الاقتصاديات المماثلة، والتي ترتفع فيها معدلات الفقر والبطالة والتهميش، فإن ما يساهم في التخفيف بشكل أكبر من تداعيات الأزمة، خصوصيات المجتمعات ومدى تجذر ثقافة التضامن داخلها، وهو تضامن غير مؤسساتي يخضع لمنطق المجتمع (جبير، 2021).

وألحقت جائحة كورونا أشـد الضرر بالفئات الفقيرة والأكثر احتياجاً، وتُنِْر الآن بسقوط ملايين من الناس

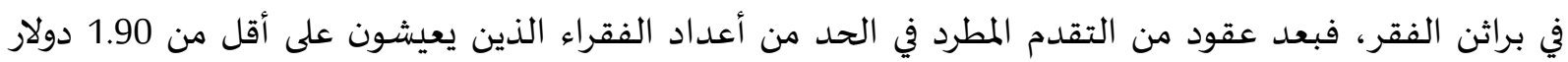

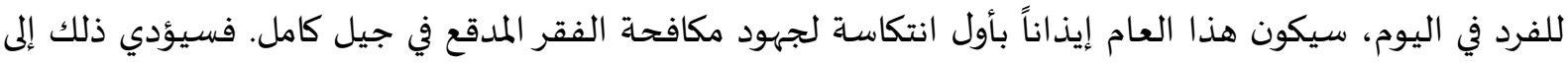

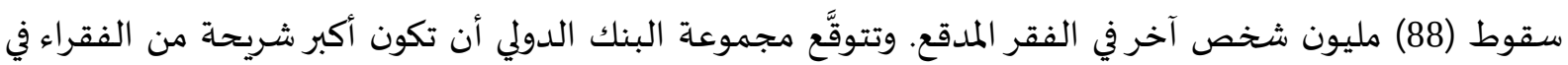

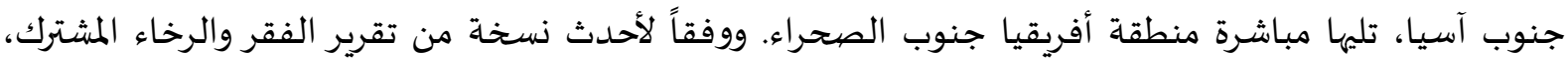

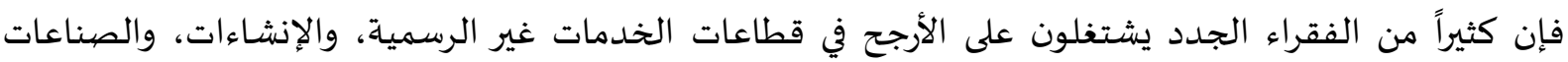

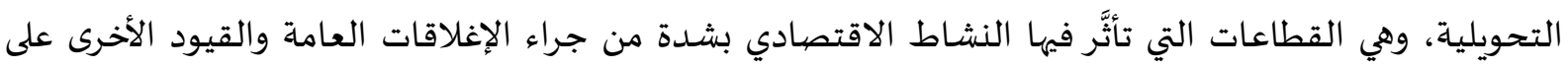

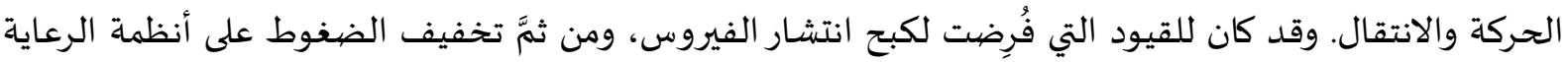

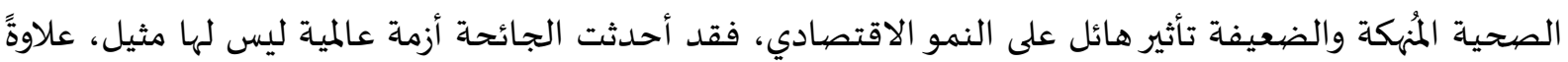

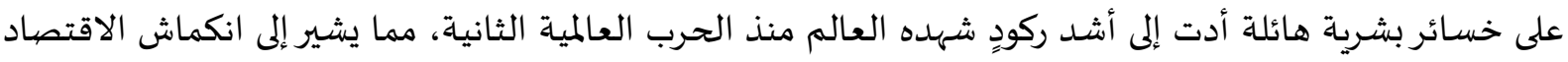

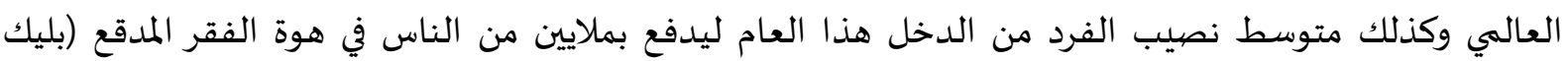
ووادوا، 2020).

ثانياً- الدراسـات السـابقة أظهر المسح المكتبي الذي أجري في العديد من المكتبات قلة الأدبيات ذات الصلة بموضوع الدراسة، وفيما يأتي بعض الدراسات التي أجريت على البيئة الأردنية والعربية والأجنبية مرتبة من الأحدث إلى الألى الأقدم: أ- دراسات سابقة بالعربية: - أجرى يونس (2020) دراسة هدفت إلى التعرف على الضغوط الاجتماعية والنفسية التي تواجه العاملين

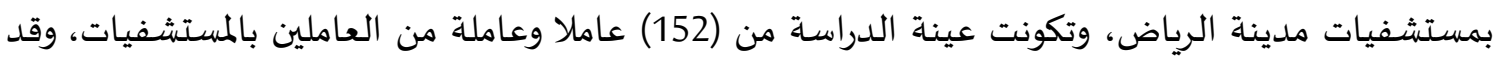

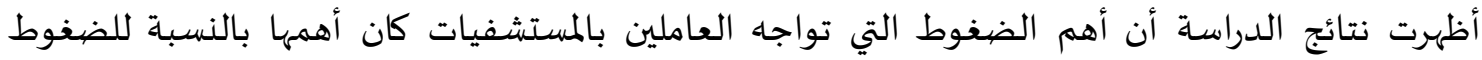

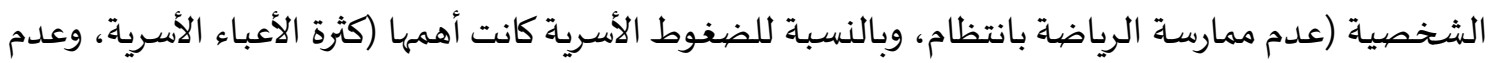


تفهه أفراد الأسرة لظروف العمل، وبالنسبة للضغوط النفسية كانت أهمها (الشعور بالملل من تكرار مهام

- أجرى راشـد وآخرون (2020) دراسة هدفت إلى التعرف على إسهام الأنشطة الترويحية في تحقيق الأمن

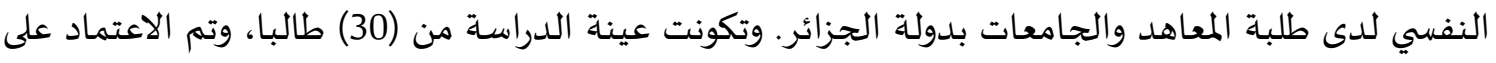

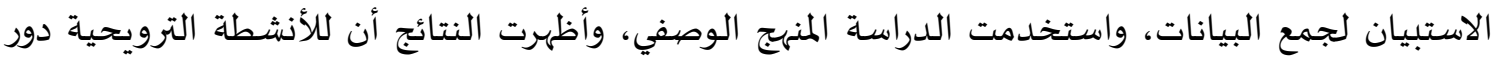

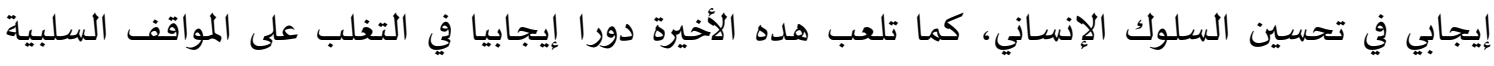
وتساهم في التغلب على الضغط وتخفف من حدة القلق والإحباط وتعتبر من الأساليب الفعالة في التخفيف

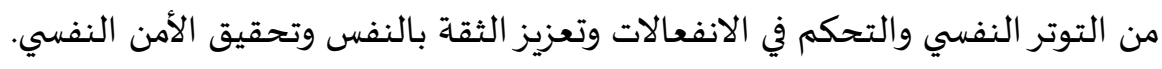

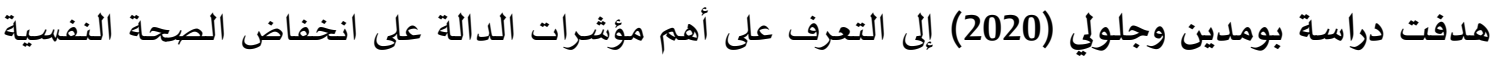

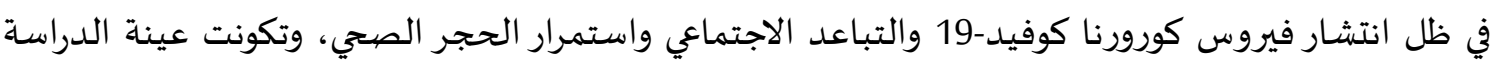

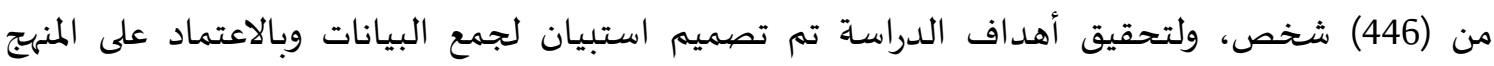

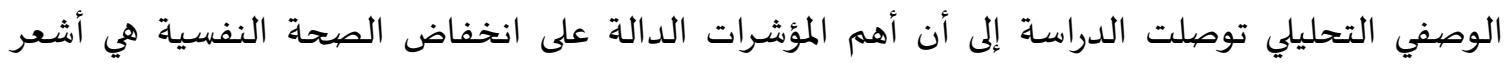

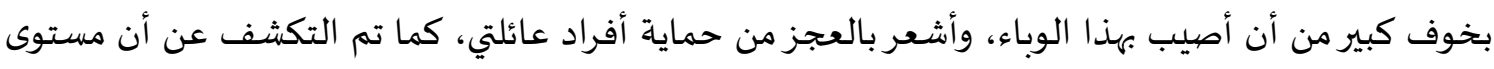

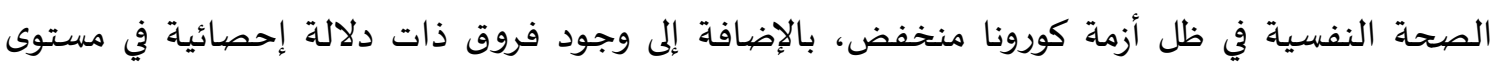
الصحة النفسية فيلا ظل أزمة كورونا تعزى لمتغير الجنس.

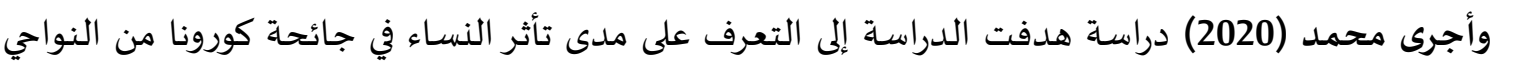

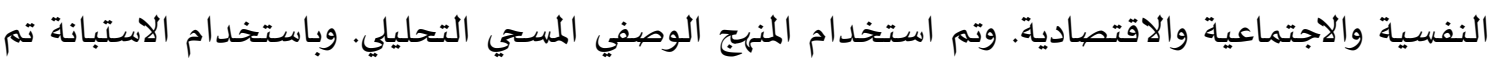

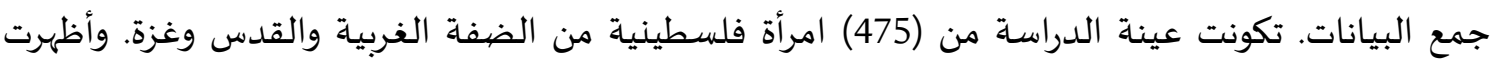

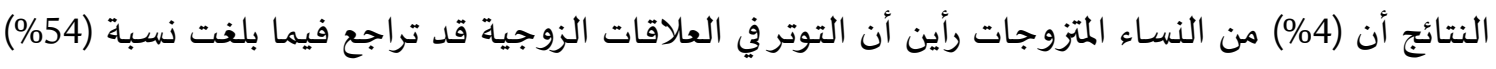

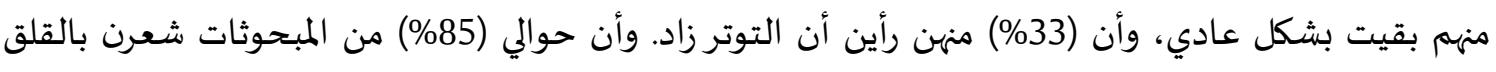

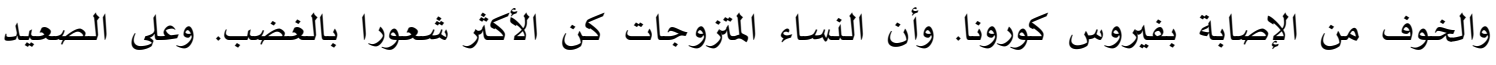

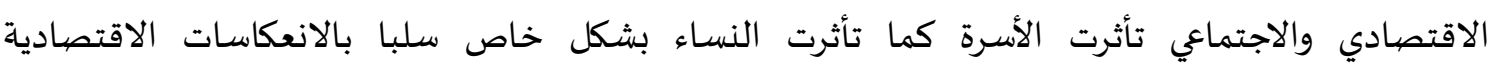
والاجتماعية للأزمة. - أجرت الهواري والهببارنة (2020) دراسة هدفت إلى العوامل المؤدية إلى التفكك الأسري وانحراف الأحداث في

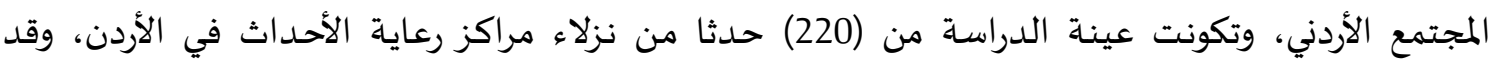

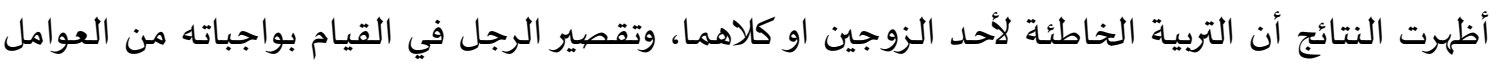

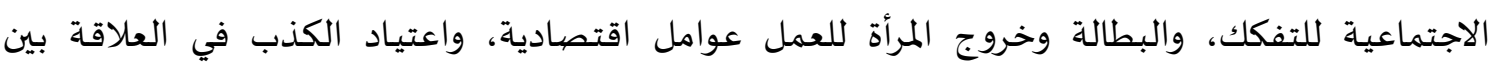

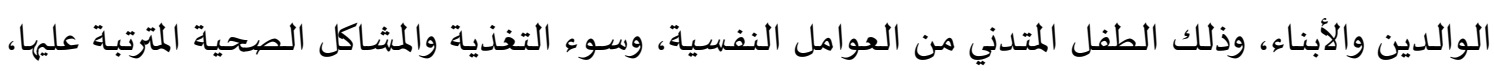

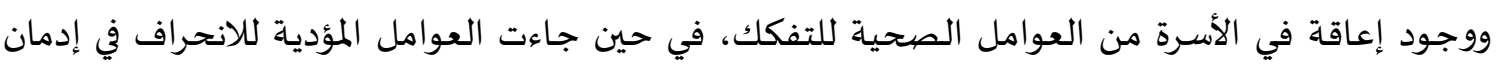

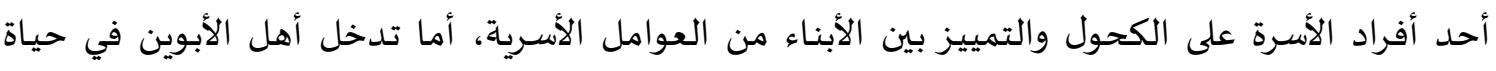

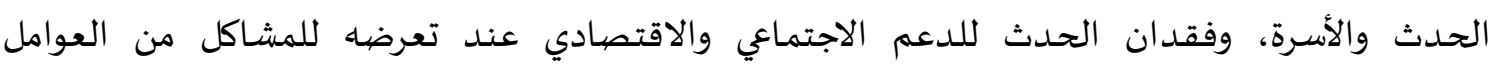

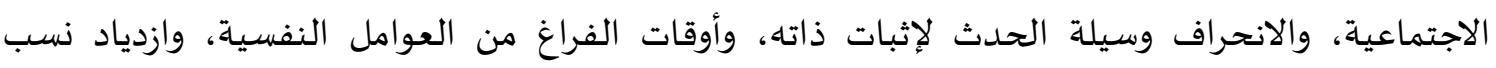

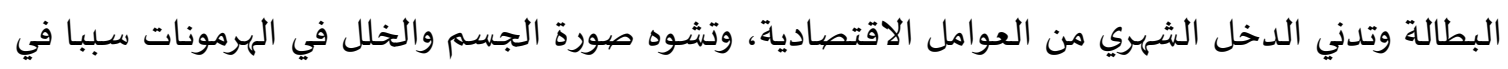

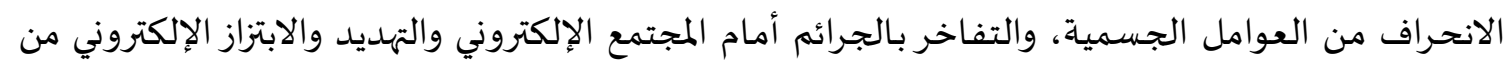
شخصيات مجهولة من العوامل التكنولوجية. 
وهدفت دراسة سـنوسي وزينب (2020) إلى التعرف على أهم مؤشرات الدالة على انخفاض الصحة النفسية

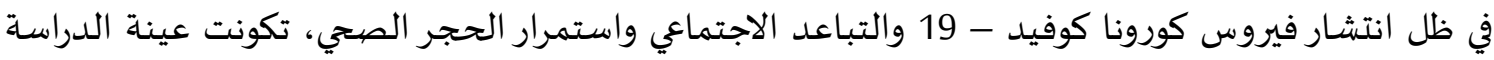

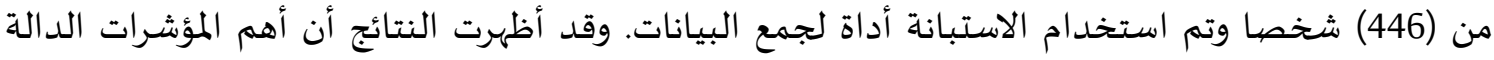
على انخفاض الصحة النفسية هي الشعور بالخوف من الإصابة بالوباء، والعجز عن حماية أفراد العائلة،

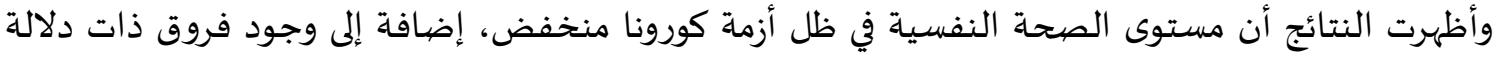
إحصائية في مستوى الصحة النفسية في ظل أزمة كورونا تعزى لمتغير الجنس.. أجرى دويفي ومرصالي وجمال (2020) دراسة هدفت إلى التعرف على مستوى القلق الاجتماعي لدى الطلبة

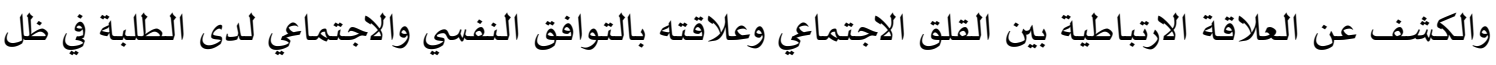

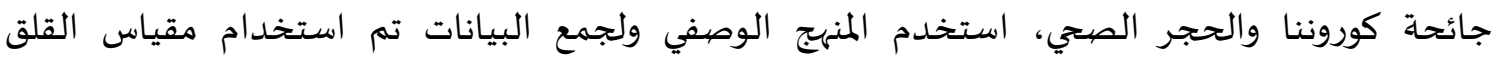

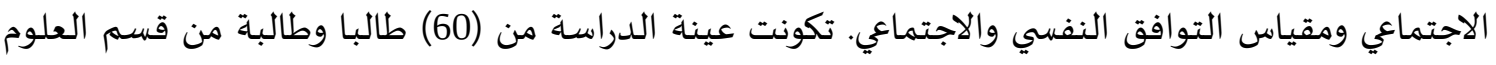

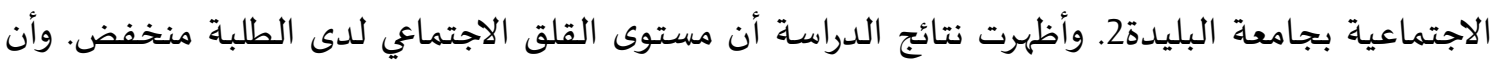
هناك علاقة ارتباطية سالبة بين القلق الاجتماعي والتوافق النفسي والاجتماعي لدى الدافي الطلبة.

ب- دراسات سابقة بالإنجليزية: قام باشال ورينجوات بدراسة (Paschal. \& Ringwalt. 2003) هدفت إلى فحص تأثير الرعاية الوالدية

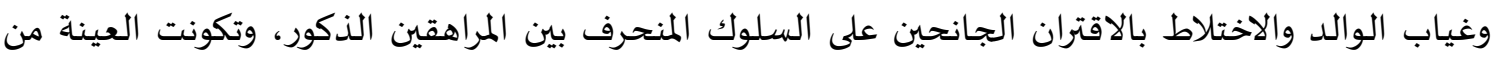

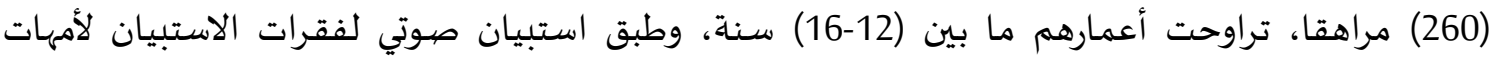

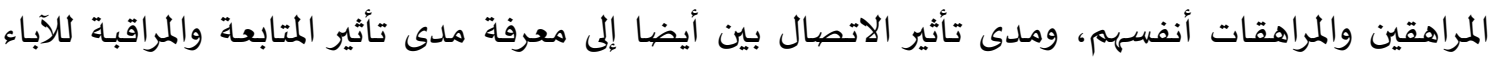

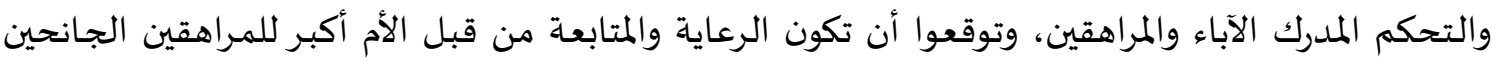

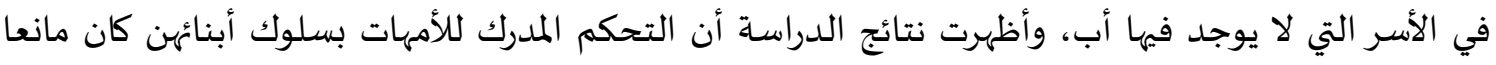

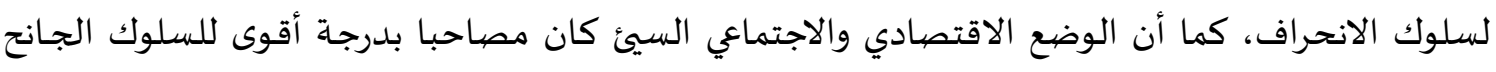

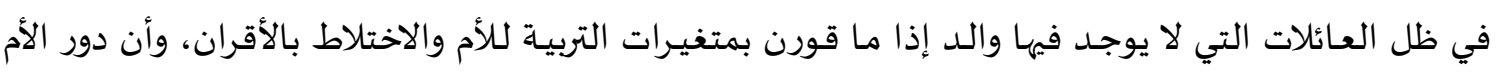

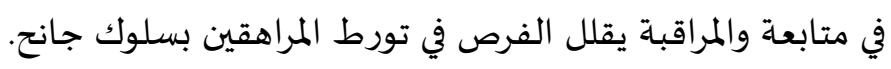

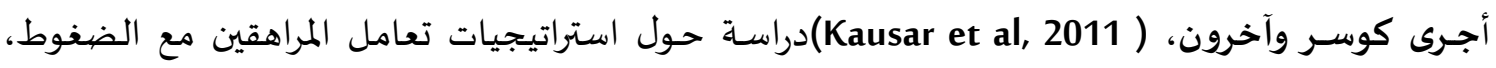

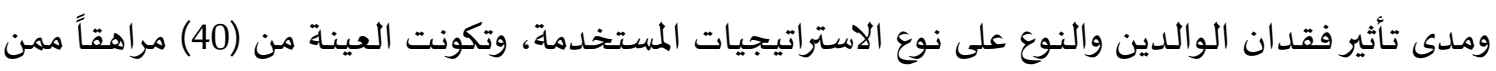

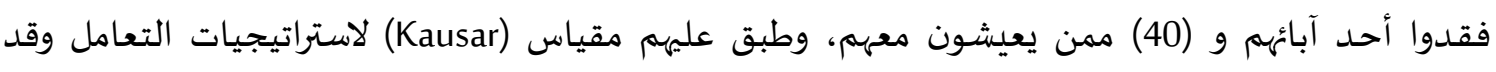

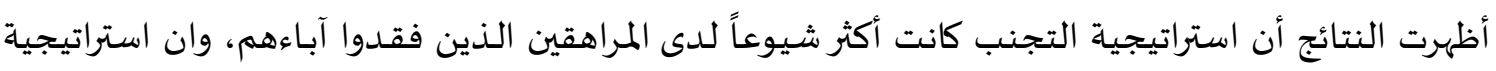

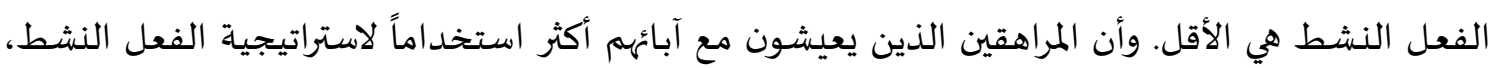

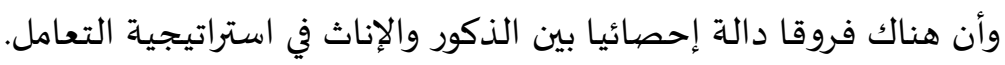
قام مسعد وآخرون (Massad, et al, 2020) بدراسـة هدفت إلى التعرف على مدى انتشار القدار القلق المرتبط

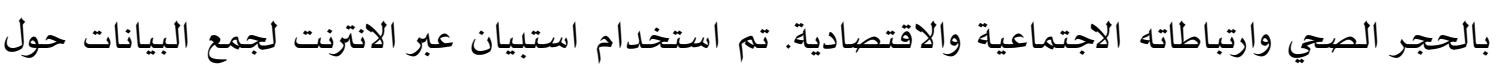

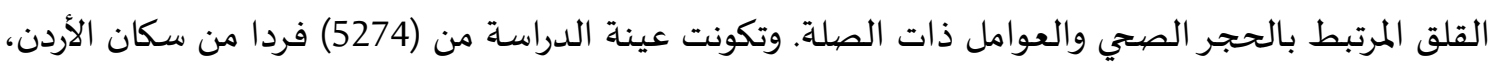

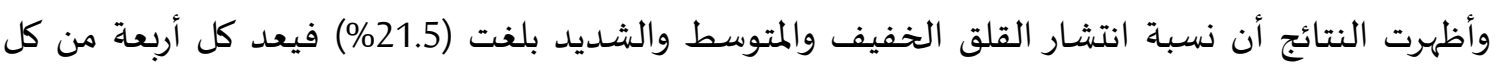

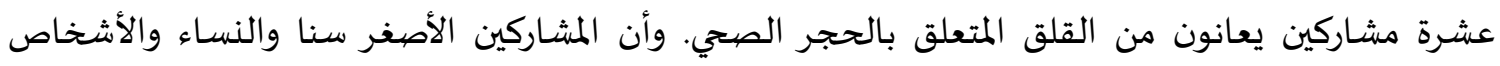

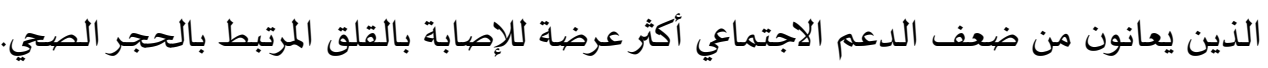


وقام شاهريراد (Shahriarirad, et al, 2020) بدراسة هدفت إلى كشف وتقييم عب المشكلات النفسية على السكان الإيرانيين بسبب تفشي كوفيد -19. وتم إجراء مشح مقطعي على شبكة الانترنت على سكان إيران إنسان

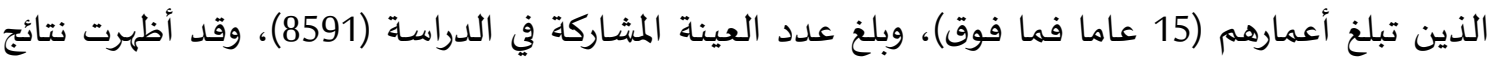
الدراسة أن ما نسبته (20.1\%) من السكان لديهم أعراض سريرية للاكتئاب والقلق وكان الاطلاع على المجلات والدوريات العالمية الصحية أحد الأسباب الوقائية من تفشي المرض. وكان التعليم كذلك أحد الأسباب

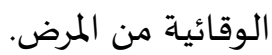
وأجرت شيفيرا وآخرون (SchAfera, et al, 2020) دراسة هدفت إلى تقييم تأثير تفشي فيروس كوفيد على الصحة العقلية والتحقق من مستويات (soc) قبل تفشي المرض على المرون التنبؤ بالتغيرات في الأعراض النفسية

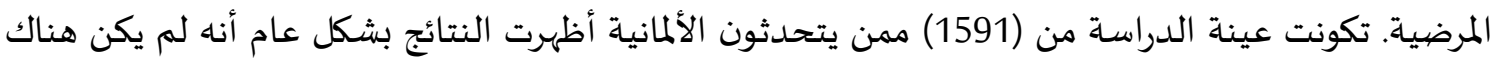
تغيير في الأعراض النفسية المرضية. وأن هناك ما نسبته (10\%) زيادة ملحوظة سرئه سيريا في الأعراض النفسية. الصحة النفسية كانت مستقرة لدى معظم المستجيبين تتميز بمستويات منخفضية.

التعقيب على الدراسـات السـابقة ويلاحظ من خلال استعراض الدراسات السابقة أنه لا يوجد دراسة تناولت العلاقة بين الضغوط الناس النفسية

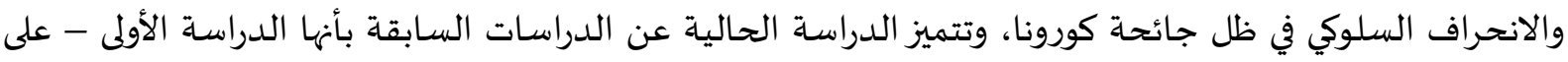

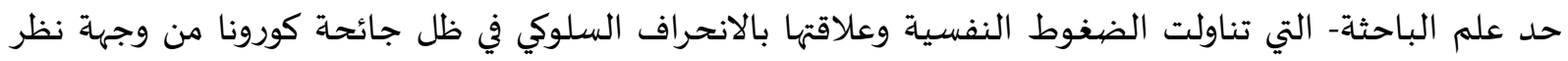
العاملين في المستشفيات الحكومية الأردنية. ورغم ذلك فإن الدراسة الحالية استفادت الدئه من الدراسات السابقة في بناء الأدب النظري، وتطوير أداة الدراسـة، وتم توظيف بعضها العائه في دعم مناقشاة نتائج الدراسـة.

3- منهجية الدراسـة وإجراءاتها.

تم استخدام المنهج الوصفي التحليلي الارتباطي لملاءمته لخدمة أهداف الدراسة.

مجتمع الدراسة وعينتها: تكون مجتمع الدراسة من جميع العاملين في المستشفيات الحكومية في الأردن، وتم اختيار عينة عشوائية

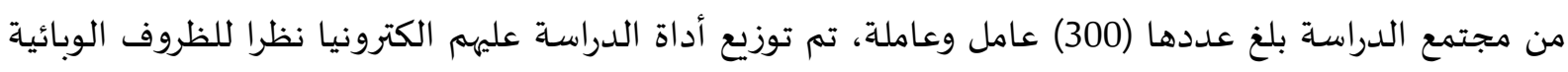

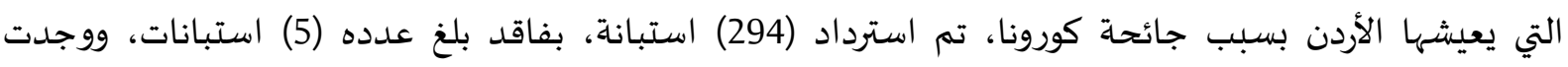
استبانة واحدة غير صالحة للتحليل الإحصائي، وبذلك أصبحت عينة الدراسة الخاضعة للتحليل الإحصائي (294)

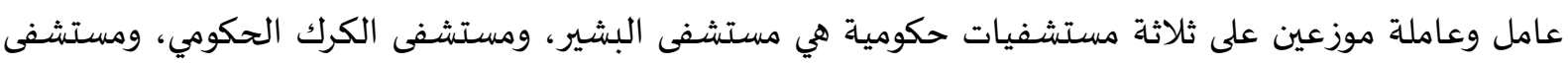
الملك المؤسس، الجدول (1) يبين توزيع أفراد عينة الدراسـة.

الجدول (1) توزيع أفراد عينة الدراسة حسب المتنغيرات (الجنس، الخبرة، الإقامة)

\begin{tabular}{|c|c|c|c|}
\hline النسبة المئوية \% & العدد & الفئات & المتغير \\
\hline$\% 74.49$ & 219 & ذكور & \multirow{2}{*}{ الجنس } \\
\hline$\% 25.51$ & 75 & إناث & \\
\hline \%100 & 294 & المجموع & \\
\hline
\end{tabular}


المجلة العربية للعلوم ونشر الأبحاث ـمجلة العوم التربوية والنفسية ـ المجلد السادس ـ العدد الساس ـ فبراير 2022م

\begin{tabular}{|c|c|c|c|}
\hline النسبة المئوية \% & 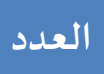 & 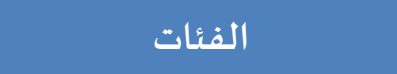 & المتغير \\
\hline$\% 31.29$ & 92 & أقل من 5 سنوات & \multirow{4}{*}{ الخبرة } \\
\hline$\% 28.91$ & 85 & من 5 سنوات - 10 سنوات & \\
\hline$\% 20.75$ & 61 & من 11-15 سنة & \\
\hline$\% 19.05$ & 56 & أكثر من 15 سنة & \\
\hline$\% 100$ & 294 & المجموع & \\
\hline$\% 44.22$ & 130 & قرية & \multirow{3}{*}{ الإقامة } \\
\hline$\% 48.30$ & 142 & 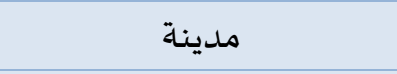 & \\
\hline$\% 7.48$ & 22 & 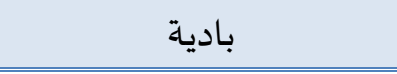 & \\
\hline$\% 100$ & 294 & \multicolumn{2}{|c|}{ المجموع } \\
\hline
\end{tabular}

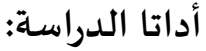

أداة الضغوط النفسية

بعد أن تم الاطلاع على الأدب النظري والمتعلق بالضغوط النفسية والانحراف السلوكي وجائحة كورونا، ومراجعة الدراسات السابقة التي أجريت حولها، تم تطوير أداتين للدراسة (الاستبانة)، وعلى النحو الآتي: 1. أداة الضغوط الاجتماعية: وتتكون من (18) فقرة موزعة على مجالين، هما:

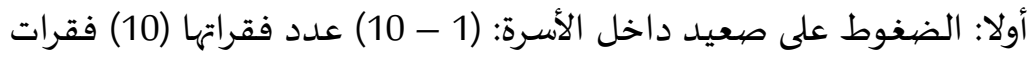
ثانيا: الضغوط على صعيد المجتمع: (11-18) عدد فقراتها (8) فقرات.

صدق أداة الضغوط الاجتماعية أولاً - الصدةق الظاهري

للتأكد من صدق الأداة تم استخراج دلالة الصدق المنطقي للأداة (صدق المحكمين)، وذلك باللجوء إلى أسلوب التحكيم من قبل مجموعة من أعضاء هيئة التدريس في الجامعات الأردنية المتخصصين، فتم توزيع الأداة عليهم، وطلب منهم الحكم على صلاحية الأداة وصلاحية فقراتها في قياس ما وضعت لقياساه، وكان الغرض من

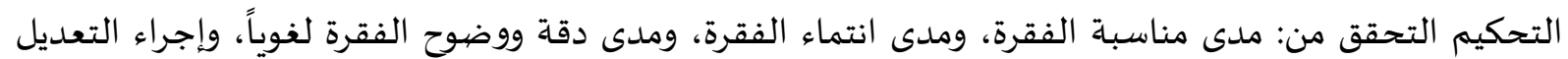
المقترح في حالة كون الفقرة غير مناسبة. وبعد إجراء التعديلات التي حددها المحكمون، تم توزيع الاستبانة بصيفتها النهائية على أفراد عينة الدراسـة.

$$
\text { ثانيًا: صددق الاتساق الداخلي لمقياس الهناء الذاتي }
$$

تم التحقق من صدق الاستبانة باستخدام صدق الاتساق الداخلي بحساب معامل ارتباط بيرسون بين

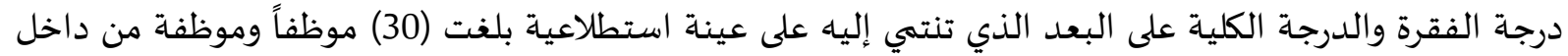

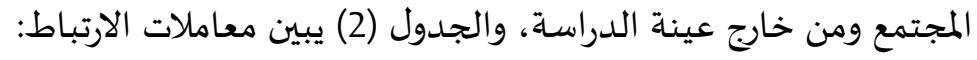


جدول (2) صداق البناء الداخلي لاستبانة الضغوط الاجتماعية

\begin{tabular}{|c|c|c|c|c|c|}
\hline معامل الاترباط & رقم الفقرة & معامل الارتباط & رقم الفقرة & معامل الارتباط & رقم الفقرة \\
\hline $.604^{* *}$ & 13 & $.592^{* *}$ & 7 & $.677^{* *}$ & 1 \\
\hline $.372^{*}$ & 14 & $.520^{* *}$ & 8 & $.542^{* *}$ & 2 \\
\hline $.614^{* *}$ & 15 & $.491^{* *}$ & 9 & $.482^{* *}$ & 3 \\
\hline $.593^{* *}$ & 16 & $.465^{* *}$ & 10 & $.585^{* *}$ & 4 \\
\hline $.652^{* *}$ & 17 & $.437^{* *}$ & 11 & $.674^{* *}$ & 5 \\
\hline $.719 * *$ & 18 & $.561^{* *}$ & 12 & $.625^{* *}$ & 6 \\
\hline
\end{tabular}

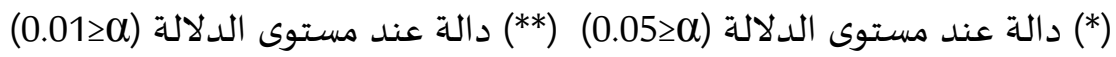

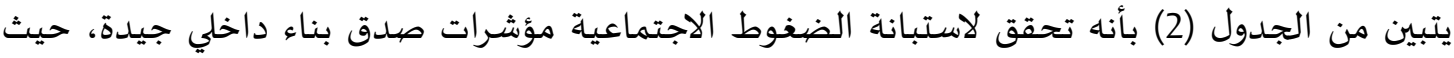

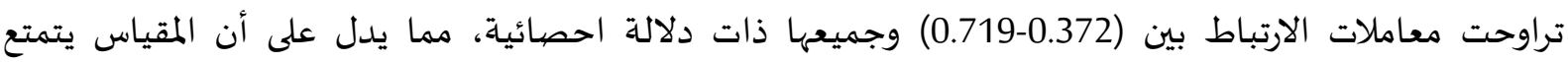
بمؤشرات صدق اتساق داخلي مناسبة.

ثبات أداة الضغوط الاجتماعية تم التحقق من ثبات الأداة بتوزيعها على عينة استطلاعية من خارج عينة الدراسة الأصلية، وتكونت من الإن

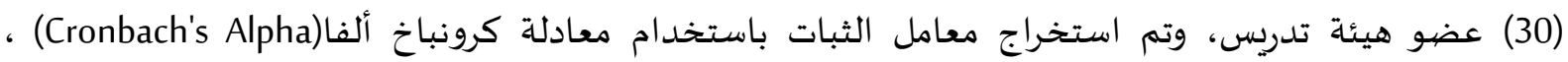
والجدول (3) يبين ذلك. الجدول (3) قيم معاملات الثبات باستخدام كرونباخ ألفا لأداة الدراسة

\begin{tabular}{|c|c|c|c|}
\hline معامل الثبات & عدد الفقرات & 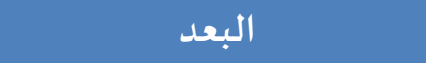 & 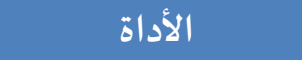 \\
\hline 0.88 & 10 & الضغوط على مستوى الأسرة & \multirow{2}{*}{ الضغوط الاجتماعية } \\
\hline 0.80 & 8 & الضغوط على مستوى المجتمع & \\
\hline
\end{tabular}

يلاحظ من خلال الجـدول (3) أن معاملات ثبات الاستقرار والتجانس الخاصة بأداة الضغوط الضغوط الاجتماعية ومجالاتها تعتبر مؤشرات كافية لأغراض إجراء الدراسة، فقد تراوح ما بين (0.80 - 0.88)، وإن معامل الثبات إذا كان أكبر من (60\%)، فهو معامل ثبات مقبول، وبناءً على ذلك معاملات الثبات المشار إليها في الجدول (2) أعلى من هذها النسبة ومقبولة لإجراء هذه الدراسة.

2. أداة السلوك الانحرافي: تم تطوير أداة لقياس السلوك الانحرافي مكونة من (15) فقرة موزعة على مجالين

$$
\text { هما: }
$$

أولا: الانحراف على صعيد داخل الأسرة: (1 - 7) عدد فقراتها (7) فقرات ثانيا: الانحراف على صعيد المجتمع: (8-15) عدد فقراتها (8) فقرات.

صدق أداة السلوك الانحرافي

أولًا: الصددق الظاهري

للتأكد من صدق الأداة تم استخراج دلالة الصدق المنطقي للأداة (صدق المحكمين)، وذلك باللجوء إلى

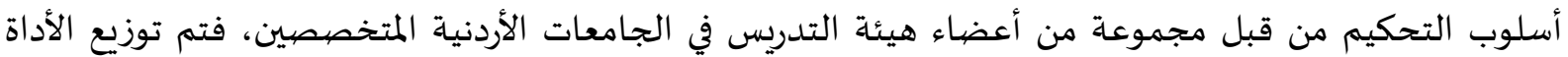


عليهم، وطلب منهم الحكم على صلاحية الأداة وصلاحية فقراتها في قياس ما وضعت لقياسه، وكان الغرض من التحكيم التحقق من: مدى مناسبة الفقرة، ومدى انتماء الفقرة، ومدى دقة ووضوح الفقرة لغوياً، وإجراء التعديل

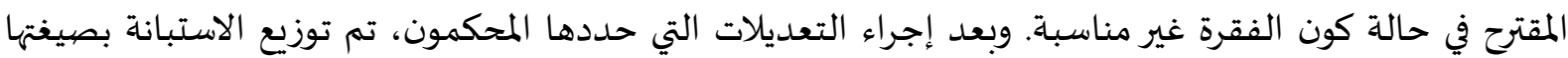
النهائية على أفراد عينة الدراسة. ثانياً: صدق الاتساق الداخلي تم التحقق من صدق المقياس باستخدام صدق الاتساق الداخلي بحساب معامل ارتباط بيرسون بين الفقرة والدرجة الكلية على البعد الذي تنتمي إليه على عينة استطلاعية بلغت (30) موظفًا وموظفة تم اختيارهم عشوائياً من داخل المجتمع ومن خارج عينة الدراسة، والجدول (4) يبين معاملات الارتباط: جدول (4) صبدق الاتساق الداخلي لاستبانة السلوك الانحرافي

\begin{tabular}{|c|c|c|c|c|c|}
\hline معامل الارتباط & رقم الفقرة & معامل الارتباط & رقم الفقرة & معامل الارتباط & رقم الفقرة \\
\hline $.437^{* *}$ & 11 & $.479^{* *}$ & 6 & $.597^{* *}$ & 1 \\
\hline $.561^{* *}$ & 12 & $.571^{* *}$ & 7 & $.602^{* *}$ & 2 \\
\hline $.374^{*}$ & 13 & $.467^{* *}$ & 8 & $.596^{* *}$ & 3 \\
\hline $.358^{*}$ & 14 & $.642^{* *}$ & 9 & $.361^{*}$ & 4 \\
\hline $.629^{* *}$ & 15 & $.525^{* *}$ & 10 & $.421^{*}$ & 5 \\
\hline
\end{tabular}

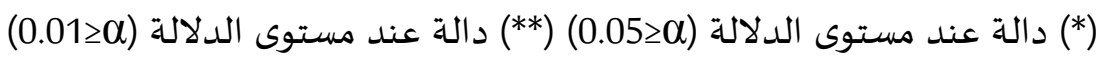

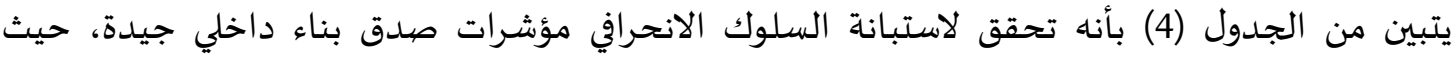
تراوحت معاملات الارتباط بين (0.642-0.361) وجميعها ذات دلالة احصائية.

ثبات أداة السلوك الانحرافي تم التحقق من ثبات الأداة بتوزيعها على عينة استطلاعية من خارج عينة الدراسة الأصلية، وتكونت من

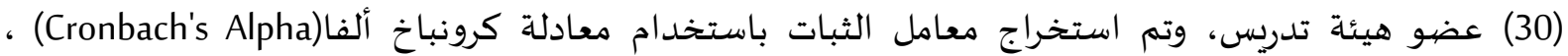
والجدول (5) يبين ذلك. الجدول (5) قيم معاملات الثبات باستخدام كرونباخ ألفا لأداة الدراسة

\begin{tabular}{|c|c|c|c|}
\hline معامل الثبات & عدد الفقرات & 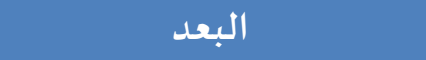 & 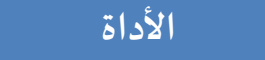 \\
\hline 0.86 & 7 & الانحراف على مستوى الأسـرة & \multirow{2}{*}{ الانحراف السلوكي } \\
\hline 0.83 & 8 & الانحراف على مستوى المجتمع & \\
\hline
\end{tabular}

يلاحظ من خلال الجدول (5) أن معاملات ثبات الاستقرار والتجانس الخاصة بأداة السلوك الانحرافي

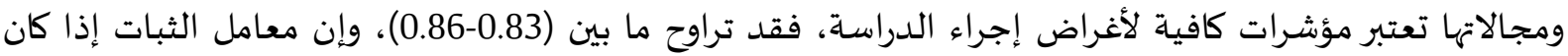

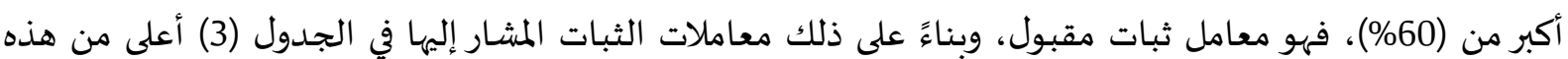
النسبة ومقبولة لإجراء هذه الدراسـة. 
للإجابة عن أسئلة الدراسة تمّ استخدام أساليب الإحصياء الوصفيّ والتحليليّ، وذلك باستخدام الرزمة

الإحصائيّة (Spss.16)، وذلك على النحو الآتي:

1. مقايس الإحصاء الوصفيّ (Descriptive statistic Measures) النسب المئويّة، والمتوسطات الحسابية

$$
\text { والانحرافات المعيارية. }
$$

2. معامل ارتباط بيرسون لاختبار العلاقة بين الضغوط النفسية والانحراف في ظل جائحة كورونا.

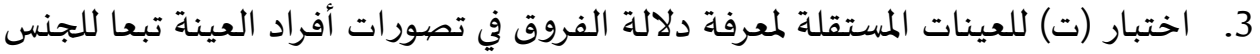

4. تحليل التباين الأحادي لمعرفة دلالة الفروق في تصورات أفراد العينة تبعا للخبرة والرتبة ومكان الإقامة.

\section{4- 1 عرض النتائج ومناقشتها.}

النتائج المتعلقة بالسؤال الأول: "ما مستوى الضغوط النفسية في ظل جائحة كورونا من وجهة نظر العاملين

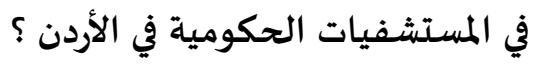

للإجابة عن السؤال تم حساب المتوسطات الحسابية والانحرافات المعيارية، والجدول المبات (6) يبين ذلك:

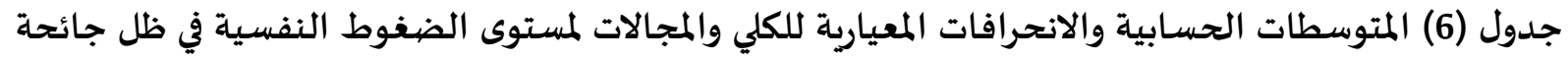

\begin{tabular}{|c|c|c|c|c|}
\hline 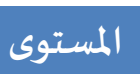 & الرتبة & الانحراف المعياري & المتوسط الحسابي & 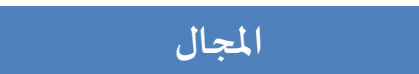 \\
\hline متوسط & 2 & 0.52 & 3.43 & الضغوط على صعيد الأسرة \\
\hline متوسط & 1 & 0.57 & 3.53 & الضغوط على صعيد المجتمع \\
\hline متوسط & - & 0.50 & 3.47 & ال الكلي \\
\hline
\end{tabular}

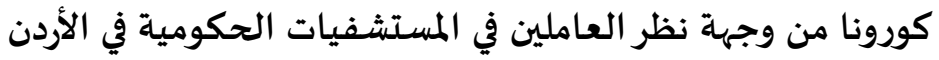

يلاحظ من خلال الجدول (6) أن مستوى الضغوط النفسية في ظل جائحة كورونا من وجهة نظر العاملين في المستشفيات الحكومية في الأردن جاء متوسطا وبمتوسط حسابي (3.47) وانحراف معياري (0.50)، حيث جاء جاء مجال (الضغوط على صعيد المجتمع) في المرتبة الأولى وبمستوى متوسط وبمتوسط حسابي (3.53) وانحراف معياري

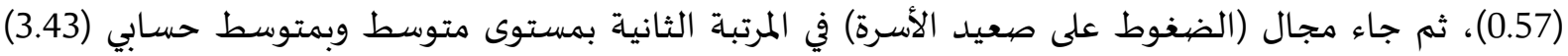
وانحراف معياري (0.52).

وهذا يعني أن انتشار جائحة كورونا وما رافقها من إجراءات وقائية أو علاجية عمل على إيجاد ضغوط

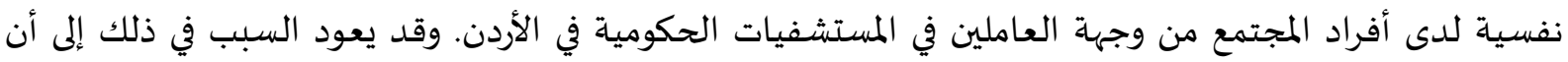

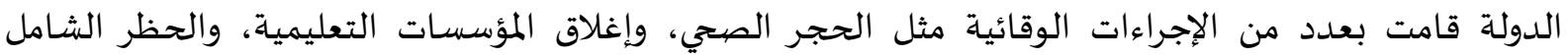

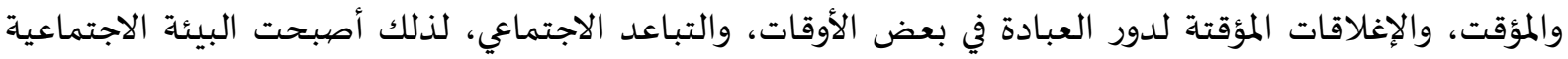

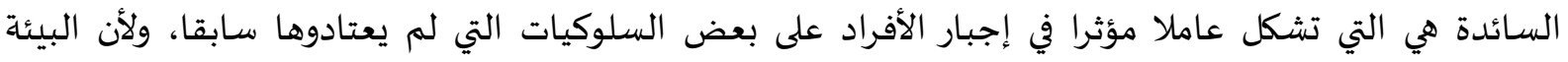

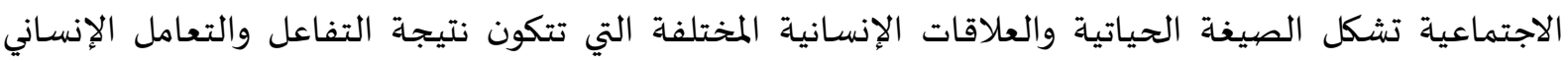

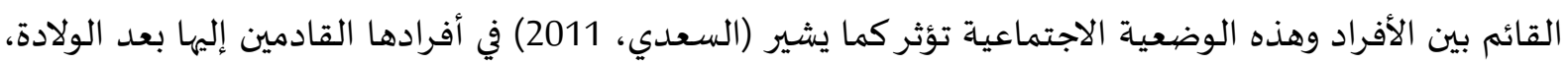

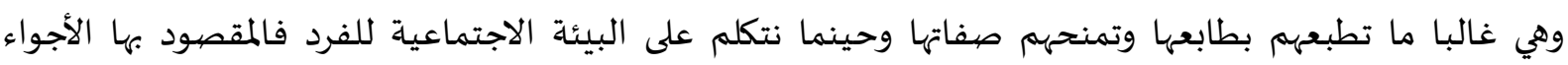
الاجتماعية التي تحتضنها، وتؤثر عليه في أدوار نموه وتكامله. 
وقد يعود السبب في ذلك أيضا إلى أن الحالة التي يعيشها المجتمع أثناء جائحة كورونا لم يعتد عليها أفراد

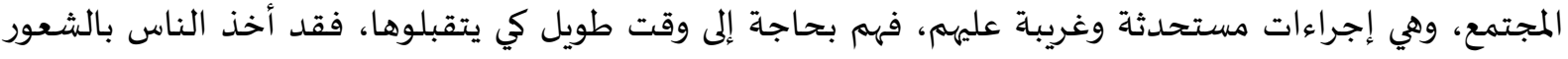

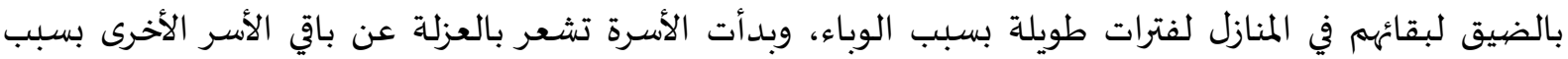

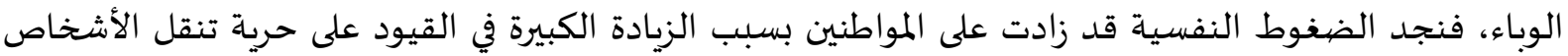

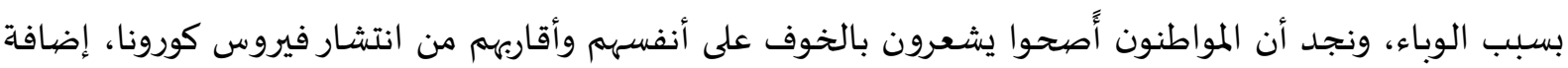

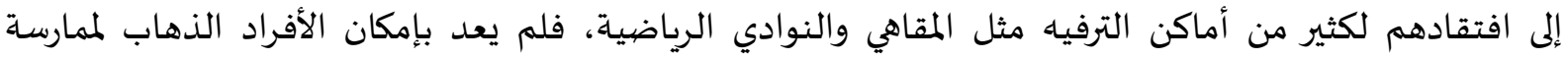

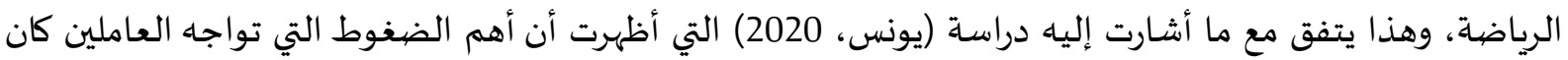

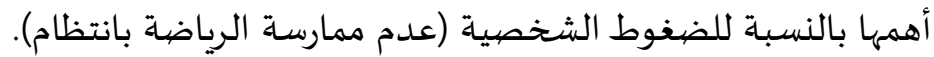
وفيما يلي المتوسطات الحسابية والانحرافات المعيارية لفقرات كل مجال من مجالات الاستبانة: 1 - مجال الضغوط على صعيد الأسرة

جدول (7) المتوسطات الحسابية والانحرافات المعيارية لفقرات الضغوط على صعيد الأسرة

\begin{tabular}{|c|c|c|c|c|c|}
\hline 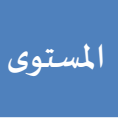 & 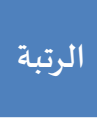 & 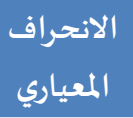 & المتوسط & 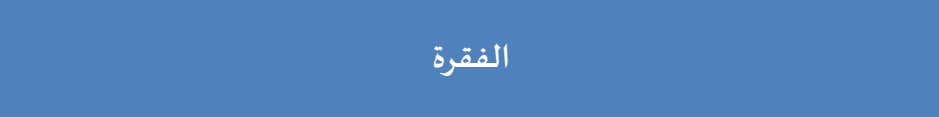 & a \\
\hline متوسط & 1 & .96 & 3.66 & ازداد شعور الأهل بالخوف على مستقبل أبنائهم الدراسي في ظل عدم وضوح الدرارية & 5 \\
\hline متوسط & 2 & .88 & 3.61 & إجراءات الوقاية الصحية أدت إلى مزيد من الضغوط النفسية & 8 \\
\hline متوسط & 3 & .92 & 3.58 & زادت الضغوط النفسية على معيلي الأسر بسبب سعيهم لتأمين احتياجات & 6 \\
\hline متوسط & 4 & .94 & 3.51 & شعر الناس بالضيق لمكوثهم في المنزل لفترات طويلة بسبب الوباء & 1 \\
\hline متوسط & 5 & .98 & 3.50 & التباعد الاجتماعي بين أفراد الأسرة أدى إلى مزيد من الضغوط للحماية من & 7 \\
\hline متوسط & 6 & .98 & 3.47 & أدى للشعور بالانعزال والضغوط النفسية عدم التزاور بين الأهل والأقارب & 3 \\
\hline متوسط & 7 & .91 & 3.38 & شعر الآباء والأمهات العاملون بفقدان الأمن الوظيفي لاحتمالية فقدانهم & 10 \\
\hline متوسط & 8 & .95 & 3.23 & 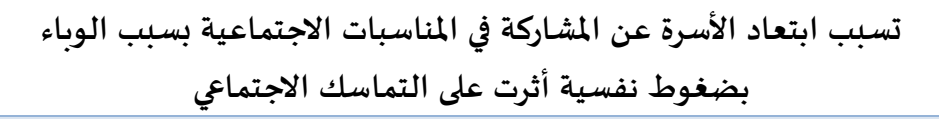 & 9 \\
\hline متوسط & 4 & .93 & 3.21 & دراسة الأبناء عن بعد أدت إلى مزيد من الضغوط النفسية على الصعيد & 4 \\
\hline 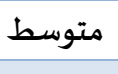 & 2 & .98 & 3.12 & شعرت الأسرة بالعزلة عن باقي الأسر الأخرى بسبب الوباء & 2 \\
\hline متوسط & --- & .52 & 3.43 & الضغوط على صعيد الأسرة & \\
\hline
\end{tabular}

يلاحظ من خلال الجدول (7) أن الفقرة رقم (5) والتي تنص على " ازداد شعور الأهل بالخوف على مستقبل

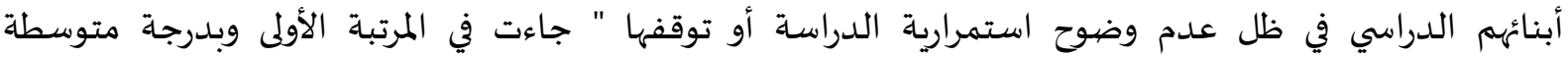

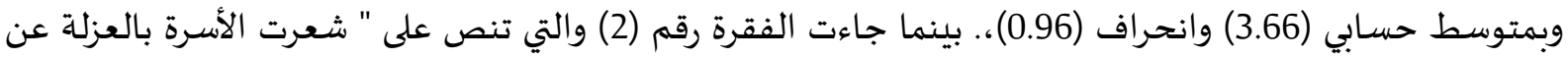
باقي الأسر الأخرى بسبب الوباء " في المرتبة الأخيرة بدرجة متوسطة وبمتوسط حسابي (3.12) وانحراف معياري 


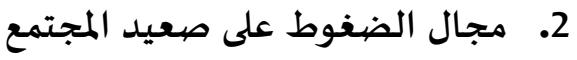

جدول (8) المتوسطات الحسابية والانحرافات المعيارية لفقرات الضغوطئ فئوط على صعيد المجتمع

\begin{tabular}{|c|c|c|c|c|c|}
\hline 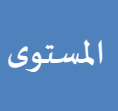 & 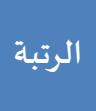 & 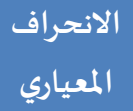 & المستوسط & 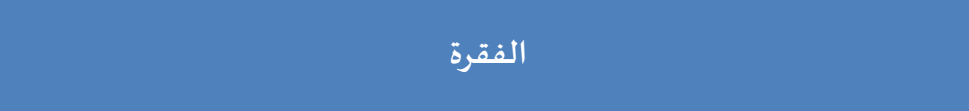 & $\hat{\imath}$ \\
\hline 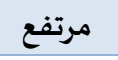 & 1 & .78 & 3.72 & عمل التباعد الاجتماعي بسبب كورونا على الشعور بنفور المواطنين & 17 \\
\hline متوسط & 2 & .92 & 3.67 & افتقد الناس للترفيه بسبب إغلاق جميع المقاهي والنوادي وكل ما يقدم أنشطة & 14 \\
\hline متوسط & 3 & .94 & 3.65 & شعر المواطنون بالضيق بسبب تعليق حركة الطيران للمسافرين والقادمين & 16 \\
\hline متوسط & 4 & .78 & 3.60 & 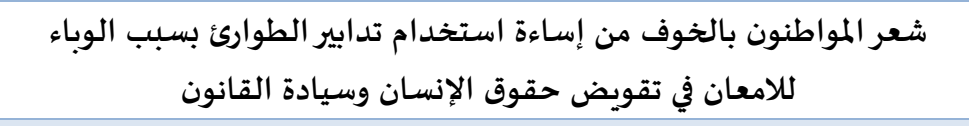 & 12 \\
\hline متوسط & 5 & .97 & 3.59 & 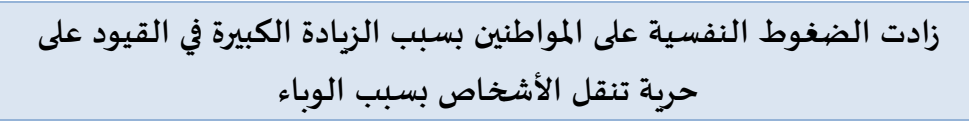 & 11 \\
\hline متوسط & 6 & .78 & 3.58 & زادت الضغوط النفسية بسبب توفير الحماية الصحية لأصحاب الأمراض المزئة & 13 \\
\hline متوسط & 7 & .96 & 3.41 & شعر المواطنون بالخوف على أنفسهم وأقاربهم من انتشار فيروس كورونا & 18 \\
\hline متوسط & 8 & .96 & 3.05 & 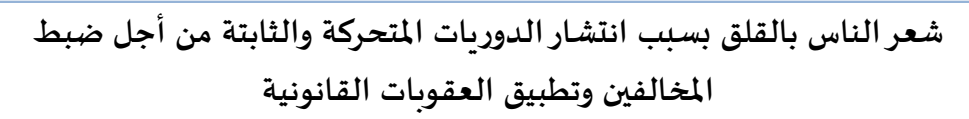 & 15 \\
\hline متوسط & --- & .57 & 3.53 & الضغوط على صعيد المجتمع & \\
\hline
\end{tabular}

يلاحظ من خلال الجدول (8) أن الفقرة رقم (17) والتي تنص على " عمل التباعد الاجتماعي بسبب كورونا على الشعور بنفور المواطنين " جاءت في المرتبة الأولى وبمستوى متوسط وبمتولماتوسط حسابي (3.72) وانحراف معياري (0.78)،. بينما جاءت الفقرة رقم (15) والتي تنص على " شعر الناس بالقلق بسبب انتشار الدوريات المتحركة والثابتة من أجل ضبط المخالفين وتطبيق العقوبات القانونية " في المرتبة الأخيرة بدرجة متوسطة وبمتوسط باكس (3.53) وانحراف

النتائج المتعلقة بالسؤال الثاني: " ما مستوى الانحراف السلوكي من وجهة نظر العاملين في المستشفيات الحكومية في الأردن؟

ولإجابة عن السؤال تم حساب المتوسطات الحسابية والانحرافات المعيارية، والجدول (9) يبين ذلك:

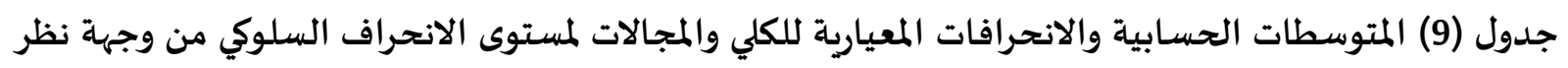

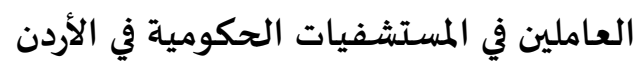

\begin{tabular}{|c|c|c|c|c|}
\hline المستوى & الرتبة & الانحراف المعياري & المتوسط الحسـابي & 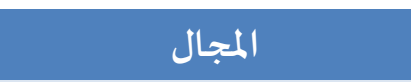 \\
\hline متوسط & 1 & 0.64 & 3.55 & الانحراف على صعيد الأسرة \\
\hline متوسط & 2 & 0.58 & 3.45 & الانحراف على صعيد المجتمع \\
\hline متوسط & - & 0.60 & 3.50 & 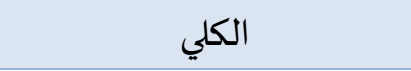 \\
\hline
\end{tabular}

يلاحظ من خلال الجدول (9) أن مستوى الانحراف السلوكي من وجهة نظر العاملين في المستشفيات الحكومية في الأردن جاء متوسطا وبمتوسط حسابي (3.50) وانحراف معياري (0.60)، حيث جاء مجال مال (الانحراف على صعيد الأسرة) في المرتبة الأولى وبمستوى متوسط وبمتوسط حستوسط حسابي (3.55) وانحراف معياري (0.60)، ثم جاء 
مجال (الانحراف على صعيد المجتمع) في المرتبة الثانية بمستوى متوسط وبمتوسط حسابي (3.45) وانحراف معياري

وهذا يعني أن هناك سلوكيات انحرافية قد ظهرت على أفراد المجتمع من وجهة نظر العاملين في

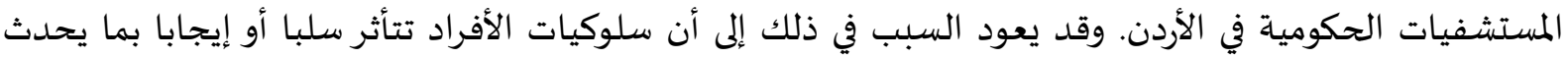

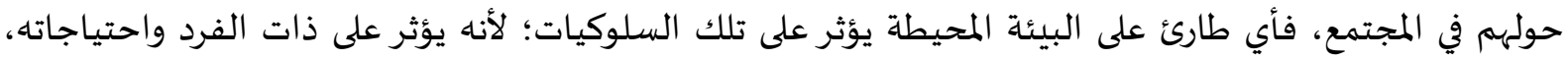
وهذا ما تشير إليه نظرية الاحتواء بأن العوامل الاجتماعية والنفسية تشكل قوة دافعة للسلوك الإنساني، فالإنسان يتعرض لنوعين من الضغوط (الضغوط الداخلية، المتمثلة في الرغبات النفسية والميول التي تدفع الفرد نحو

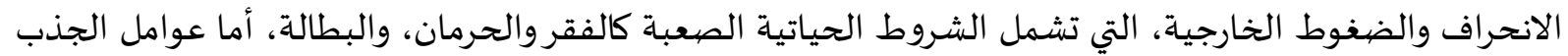
الخارجية التي تشمل جماعاة الرفاق المنحرفين وهي من العوامل التي تدفع الأفراد نحو السلوكيات الانحرافية (Katherine, 2004). وهذه الأسباب الدافعة للانحراف تتفق مع نتائج دراسة (حمد، 2008) التي أظهرت إمكانية

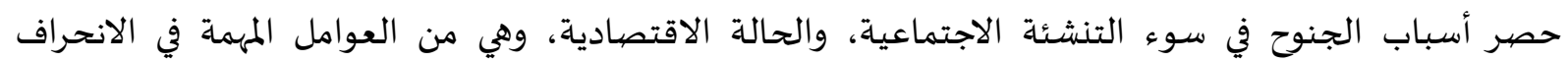
السلوكي لأن الفرد يفتقد لتأمين احتياجاته ورغباته.

وفيما يلي المتوسطات الحسابية والانحرافات المعيارية لفقرات ولفياتهات كل مجال من مجالات الأداة:

$$
\text { 1. مجال الانحراف على صعيد الأسرة }
$$

جدول (10) المتوسطات الحسابية والانحرافات المعيارية لفقرات السلوك الانحرافيد الاهرة

\begin{tabular}{|c|c|c|c|c|c|}
\hline المستوى & الرتبة & الاندراف & المتوسـا & 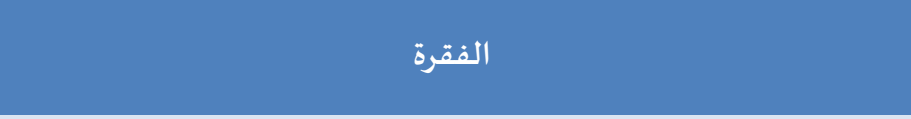 & $\hat{\imath}$ \\
\hline 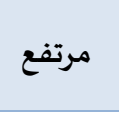 & 1 & 0.98 & 3.68 & قد تجعل الضغوط النفسية الآباء يلجؤون إلى استخدام العنف للسيطرة & 5 \\
\hline متوسط & 2 & 0.93 & 3.64 & 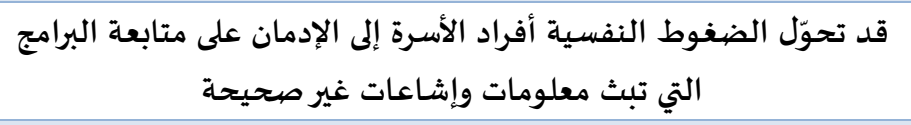 & 3 \\
\hline متوسط & 3 & 0.88 & 3.60 & 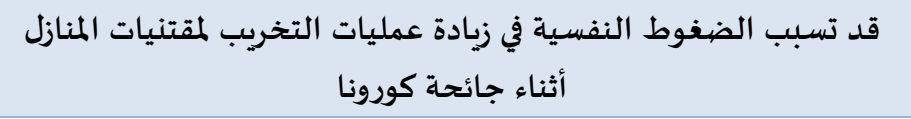 & 7 \\
\hline متوسط & 4 & 0.98 & 3.58 & قد تؤدي الضغوط النفسية بسبب الوباء إلى لجوء بعض أرباب الأسر إلى السرقة & 4 \\
\hline متوسط & 5 & 0.92 & 3.57 & 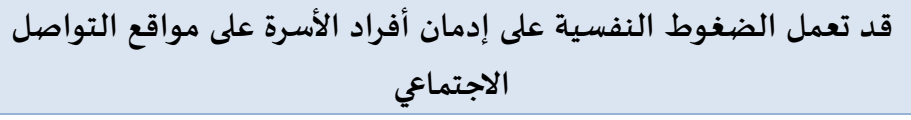 & 2 \\
\hline متوسط & 6 & 0.83 & 3.50 & قد تؤدي الضغوط النفسية بأولياء الأمور لاستخدام العنف ضيد الأبناء & 6 \\
\hline متوسط & 7 & 0.90 & 3.29 & قد تعمل الضغوط النفسية على ظهور التفكك الأسري لدى أفراد الأسرة & 1 \\
\hline متوسط & --- & 0.64 & 3.55 & الضغوط النفسية على صعيد الأسرة & \\
\hline
\end{tabular}

يلاحظ من خلال الجدول (10) أن الفقرة رقم (5) والتي تنص على " قد تجعل الضغوط النفوة النفسية الآباء يلجؤون إلى استخدام العنف للسيطرة على سلوكيات أفراد الأسرة" جاءت في المرتبة الأولى وبدرجة متوسطة الفئل

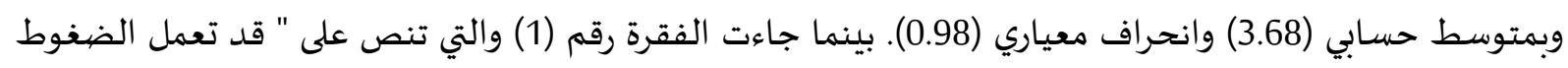

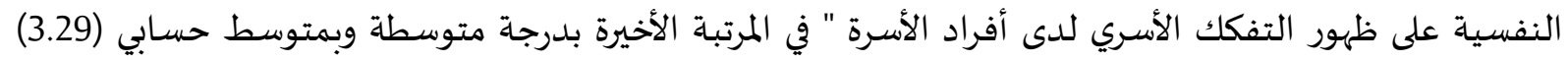
وانحراف معياري (0.90). 
2. مجال الانحراف على صعيد المجتمع

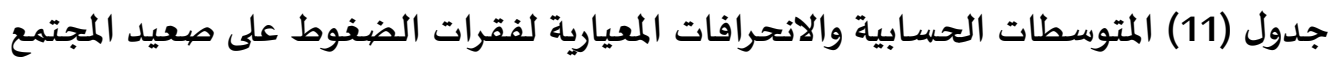

\begin{tabular}{|c|c|c|c|c|c|}
\hline 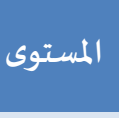 & 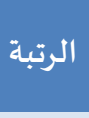 & 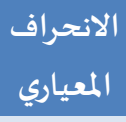 & المتوسط الحسابي & 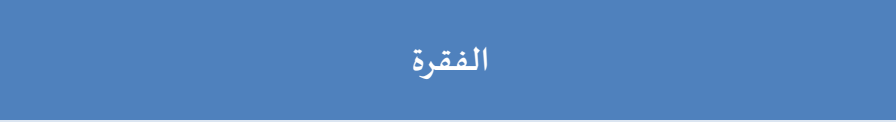 & $\hat{\imath}$ \\
\hline 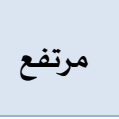 & 1 & 0.95 & 3.69 & قد تقود الضغوط النفسية إلى التزاحم عند المخابز والمتاجر مما يسبب إيجاد بعض مظاهر العنف & 10 \\
\hline متوسط & 2 & 0.91 & 3.58 & قد تُظهر الضغوط النفسية الاعتداء على الممتلكات العامة والخاصهة من & 13 \\
\hline متوسط & 3 & 0.98 & 3.57 & قد تؤدي الضغوط النفسية إلى اتجاه أفراد المجتمع نحو المواقع الإباحية & 9 \\
\hline 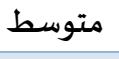 & 4 & 0.93 & 3.44 & قد تؤدي الضغوط النفسية إلى جرائم قتل على الصعيد المجتمعي & 14 \\
\hline متوسط & 5 & 0.98 & 3.41 & قد تجعل الضغوط النفسية أفراد المجتمع يتمردون على القوانين & 12 \\
\hline 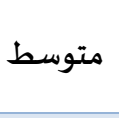 & 6 & 0.85 & 3.40 & قد تقود الضغوط النفسية إلى زيادة عمليات النصب والاحتيال عبر & 8 \\
\hline 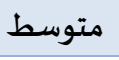 & 7 & 0.93 & 3.34 & قد يؤدي الحظر بسبب الوباء إلى زيادة جرائم الأحداث في المجتمع & 15 \\
\hline 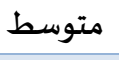 & 8 & 0.89 & 3.19 & قد تقود الضغوط النفسية المواطنين إلى الاعتداء على رجال الأمن العام & 11 \\
\hline 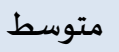 & --- & 0.58 & 3.45 & الضغوط على صعيد المجتمع & \\
\hline
\end{tabular}

يلاحظ من خلال الجدول (11) أن الفقرة رقم (10) والتي تنص على " قد تقود الضغوط النفان النفسية إلى

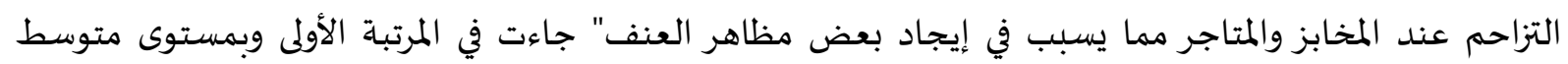

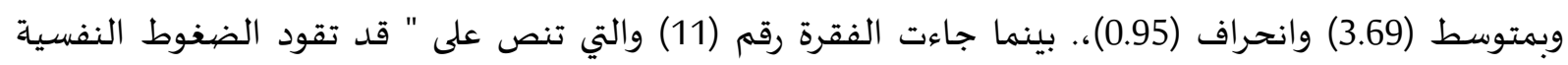

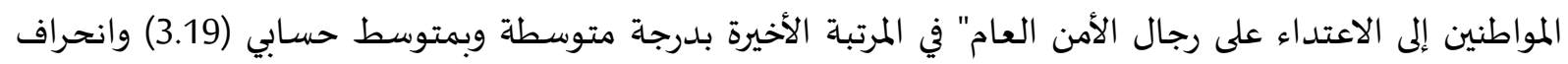

النتائج المتعلقة بالسؤال الثالث: " ما علاقة الضغوط النفسية بالانحراف السلوكي في ظل جائحة كورونا

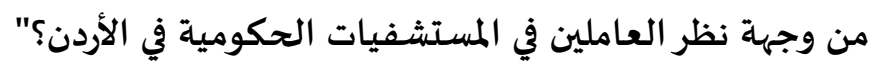

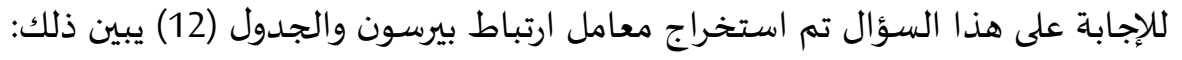
جدول (12) معامل ارتباط بيرسون للعلاقة بين الضغوط النفسية والانحراف السلوكي في ظل جائحة كورونا من

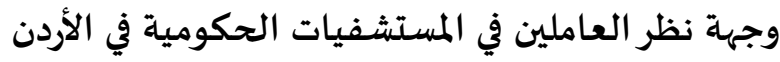

\begin{tabular}{|c|c|c|c|}
\hline الانحراف الكلي & الانحراف على صيعيد المجتمع & الانحراف على صيعيد الأسرة & \\
\hline $.691^{* *}$ & $.671^{* *}$ & $.619^{* *}$ & الضغوط على صعيد الأسرة \\
\hline $.766^{* *}$ & $.669^{* *}$ & $.773^{* *}$ & الضغوط على صعيد المجتمع \\
\hline $.796^{* *}$ & $.735^{* *}$ & $.758^{* *}$ & الضغوط الكلي \\
\hline
\end{tabular}

يتبين من الجدول (12) وجود علاقة ارتباطية ايجابية ذات دلالة إحصائية بين الضغوط النفسية

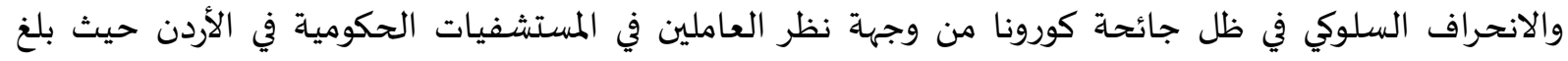

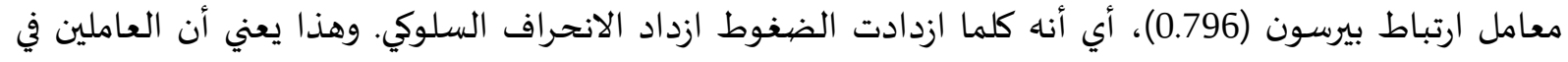
المستشفيات الحكومية في الأردن يرون أن الضغوط النفسية التي يتعرض لها المجتمع الأردني بسبب جائحة كورونا 
والإجراءات المتخذة بسبها عملت على الانحراف السلوكي عند بعض الأفراد، فالضغوط النفسية سواء على مستوى

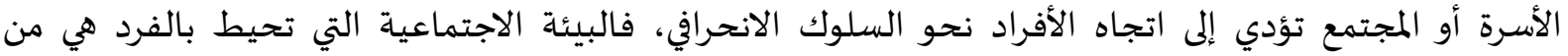
العوامل المؤثرة في اتجاه السلوكيات، وقد فسرت نظرية الاحتواء السلوك الانحراف اعتمادا على الضغوط التي يتعرض لها الفرد سواء الضغوط الداخلية أم الخارجية فهي التي تدفع بالفرد نحو الانحراف مثل العدوان والإحباط والغضب والتوتر، فيكون الفرد بحاجة إلى الإشباع الآني، إضافة إلى تأثير الضغوط الاجتماعية المحيطة التي تتعلق بالبيئة الاقتصادية مثل الفقروالبطالة (Katherine, 2004). واتفقت هذه النتيجة مع نتائج دراسة (البلوي، 2010) التي أظهرت أن الضغوط الاجتماعية، والضغوط الاقتصادية ساهمت في جنوح الأحداث في منطقة حائل. واتفقت كذلك مع نتائج بنجابي (2009) التي أظهرت وجود علاقة ارتباطية موجبة بين الضغوط والأمراض السيكوسوماتية. واتفقت مع نتائج دراسة (حمد، 2008) التي أظهرت أنه يمكن حصر أسباب الجنوح عند الأحداث في سوء التنشئة الاجتماعية، والحالة الاقتصادية، والإهمال الزائد.

النتائج المتعلقة بالسؤال الرابع: " هل توجد فروق ذات دلالة إحصائية عند مستوى (0.05) لتصورات أفراد عينة الدراسة نحو الضغوط النفسية وعلاقتها بالانحراف السلوكي في ظل جائحة كورونا من وجهة نظر العاملين في المستشفيات الحكومية في الأردن تعزى للمتغيرات الديمغرافية (الجنس، الخبرة الوظيفية، الإقامة)؟؟

أولا: الجذس: تم استخدام اختبار (ت) للعينات المستقلة لمعرفة دلالة الفروق في تصورات من وجهة نظر العاملين في المستشفيات الحكومية في الأردن نحو الضغوط النفسية وعلاقتها بالانحراف السلوكي في ظل جائحة كورونا تبعا للجنس.

جدول (13) نتائج اختبار (ت) للعينات المستقلة لمعرفة دلالة الفروق في تصورات أفراد عينة الدراسة نحو

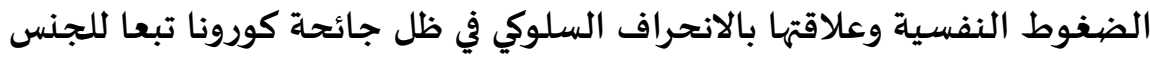

\begin{tabular}{|c|c|c|c|c|c|c|}
\hline مستوى الدلالة & قيمة (ت) & درجة الحرية & المتوسطات الحسابية & 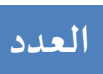 & الفئات & المتغير \\
\hline \multirow{2}{*}{.871} & \multirow{2}{*}{-.163} & \multirow{4}{*}{292} & 3.4721 & 219 & ذكر & \multirow{2}{*}{ الضغوط } \\
\hline & & & 3.4830 & 75 & أنثى أن & \\
\hline \multirow{2}{*}{.466} & \multirow{2}{*}{-.730} & & 3.4843 & 219 & ذكر & \multirow{2}{*}{ الانحراف } \\
\hline & & & 3.5431 & 75 & 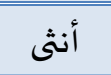 & \\
\hline
\end{tabular}

يتبين من النتائج الواردة في الجدول (13) عدم وجود فروق ذات دلالة إحصائيةً عند مستوى دلالة

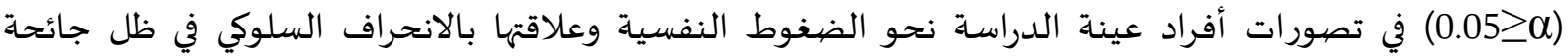
كورونا تبعا للجنس حيث بلغت قيم (ت) المحسوبة للكلي= (-0.163 و-0.730).

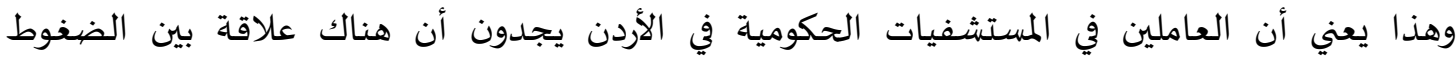

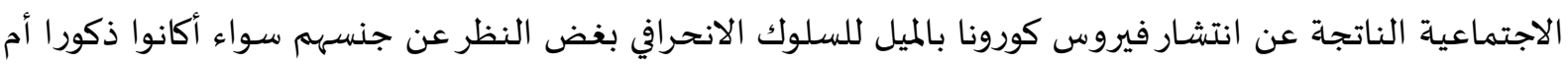

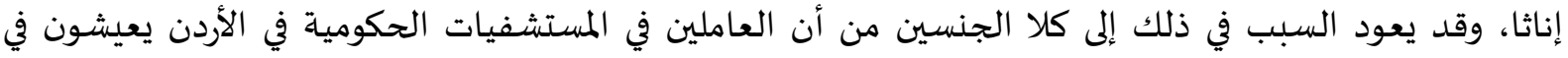
مجتمع واحد، ذو ثقافة واحدة، ويعيشون الحالة الاجتماعية التي ترافق جائحة كورونا، لذلك لان لا تتأثر تصوراتهيم

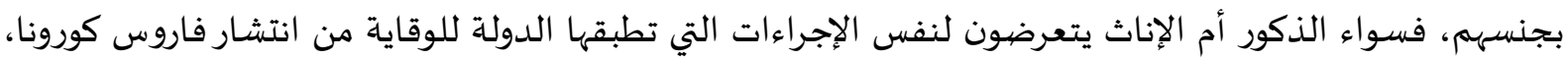

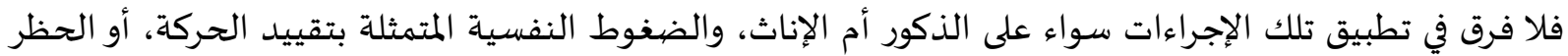

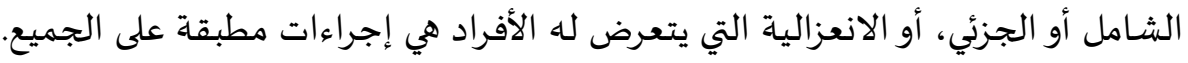


ثانيا: الخبرة: تم استخدام تحليل التباين الأحادي لمعرفة دلالة الفروق في تصورات أفراد عينة الدراسة نحو

الضغوط النفسية وعلاقتها بالانحراف السلوكي تبعا للخبرة كما في الجدول (14):

جدول (14) تحليل التباين الأحادي للفروق في تصيورات أفراد عينة الدراسة نحو الضغوط النفسية وعلاقتها

بالانحراف السلوكي في ظل جائحة كورونا تبعا للخبرة

\begin{tabular}{|c|c|c|c|c|c|c|c|c|c|}
\hline مستوى الدلالة & قيمة (ف) & المربعات & الحربة & المربعات & مصدر التباين & الحستوسطي & العدد & الخبرة & المتغير \\
\hline \multirow[t]{4}{*}{.211} & 1.515 & .375 & 3 & 1.125 & بين المجموعات & 3.5326 & 92 & 1 & \multirow{4}{*}{ الضغوط } \\
\hline & & .247 & 290 & 71.748 & الخطأ & 3.4686 & 85 & 2 & \\
\hline & & & 293 & 72.873 & الكلي & 3.3643 & 61 & 3 & \\
\hline & & & & & & 3.5099 & 56 & 4 & \\
\hline \multirow[t]{4}{*}{.371} & 1.049 & .379 & 3 & 1.138 & بين المجموعات & 3.5848 & 92 & 1 & \multirow{4}{*}{ الانحراف } \\
\hline & & .361 & 290 & 104.815 & الخطأ & 3.4878 & 85 & 2 & \\
\hline & & & 293 & 105.953 & الكلي & 3.4601 & 61 & 3 & \\
\hline & & & & & & 3.4190 & 56 & 4 & \\
\hline
\end{tabular}

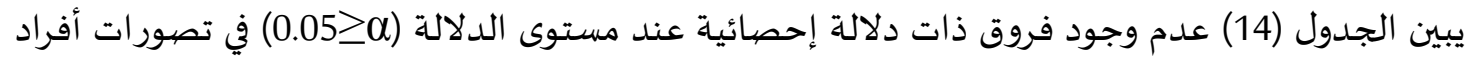
عينة الدراسة نحو الضغوط النفسية وعلاقتها بالانحراف السلوكي في ظل جائحة كورونا تبعا للخبرة بين حيث كانت قيمة (ف)= (1.515، 1.049).

وهذا يعني أن العاملين في المستشفيات الحكومية في الأردن يجدون علاقة بين الضغوط الاجتماعية الناتجة عن انتشار فيروس كورونا والميل للسلوك الانحرافي بغض النظر عن خبرتهم في العمل في الجامعات سواء أكان أكانت طويلة

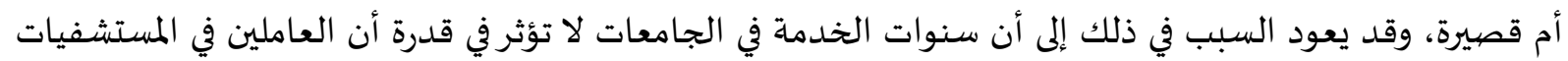

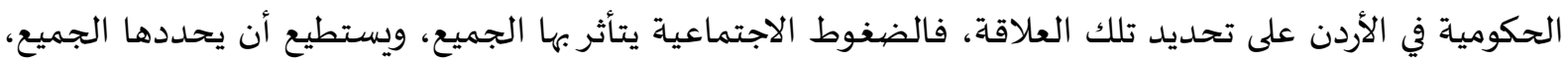

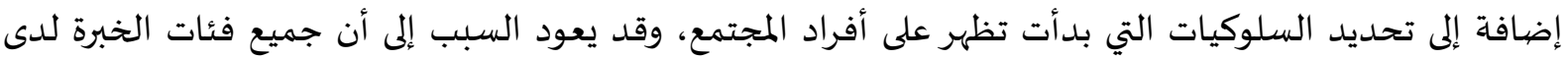

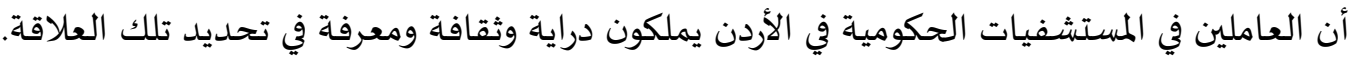

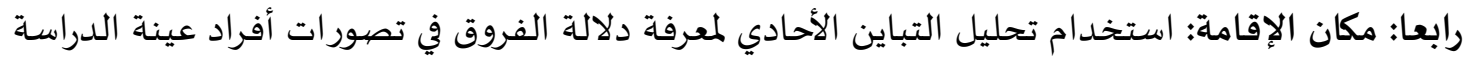

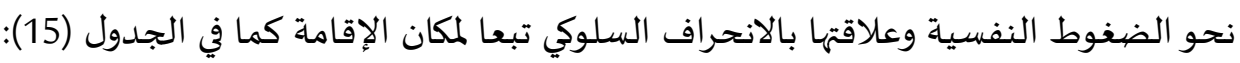

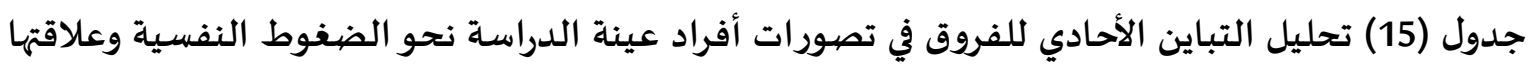

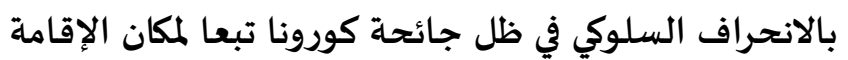

\begin{tabular}{|c|c|c|c|c|c|c|c|c|c|}
\hline مستوى الدلالة & قيمة (ف) & متوسط المربعات & الحربة & المربعات & مصدر التباين & المستوسطي & العدد & مكان & المتغير \\
\hline \multirow[t]{3}{*}{.301} & 1.207 & .300 & 2 & .599 & بين المجموعات & 3.5209 & 130 & قرية & \multirow{3}{*}{ الضغوط } \\
\hline & & 248 & 291 & 72.274 & الخطأ & 3.4284 & 142 & مدينة & \\
\hline & & & 293 & 72.873 & الكلي & 3.5025 & 22 & بادية & \\
\hline \multirow[t]{3}{*}{.251} & 1.391 & .502 & 2 & 1.003 & بين المجموعات & 3.5241 & 130 & قرية & \multirow{3}{*}{ الانحراف } \\
\hline & & .361 & 291 & 104.950 & الخطأ & 3.4512 & 142 & مدينة & \\
\hline & & & 293 & 105.953 & الكلي & 3.6636 & 22 & بادية & \\
\hline
\end{tabular}


يبين الجدول (15) عدم وجود فروق ذات دلالة إحصائية عند مستوى الدلالة (0.05 0. في تصورات أفراد

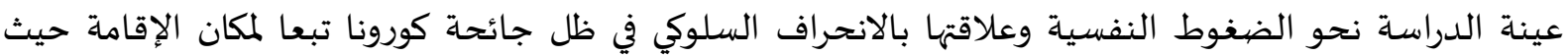

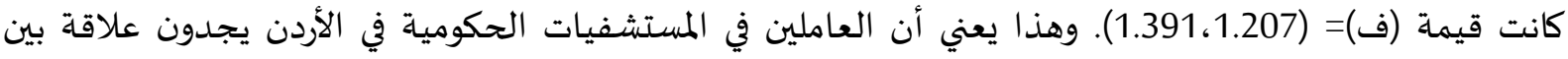
الضغوط النفسية والانحراف السلوكي في ظل جائحة كورونا بغض النظر عن منطقة سكنهم الأصلية سواء أكانت

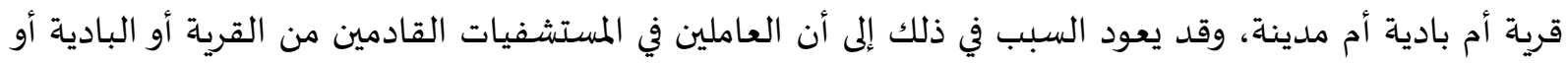
المدينة هم على سوية واحدة في الثقافة والمعرفة، وهم يحملون التقاليد الاجتماعية والقيم المتقاربة لأههم جميعا ينتمون إلى المجتمع الأردني الواحد، والمجتمع الأردني بصفته العمومية هو مجتمع يخضع للعادات والتهات والتقاليد والقيم

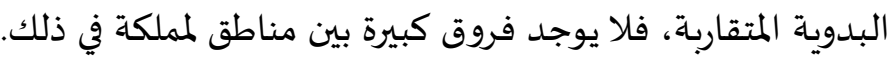

التوصيات والمقترحات.

بناء على نتائج الدراسة توصي الباحثة وتقترح ما يلي:

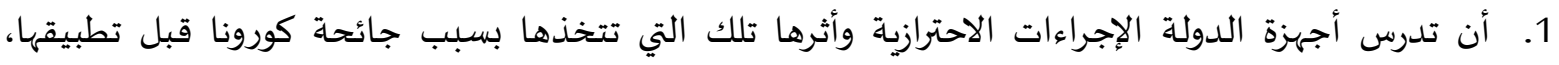
والأخذ بتخفيف الضغوط النفسية وتقييم تلك الإجراءات باستمرار.

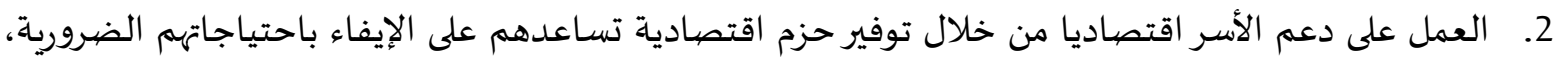

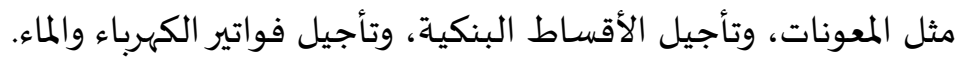

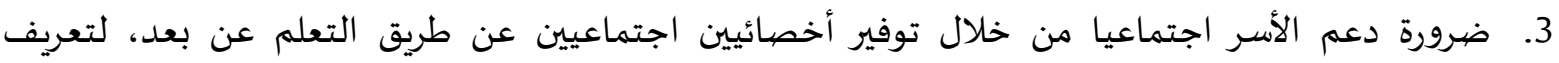

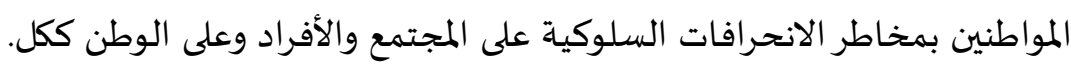

- - أبو عليان، بسام، (2012)، الانحراف الاجتماعي والجريمة، فلسطين، دار الكتب للنشر وللتوزيع.

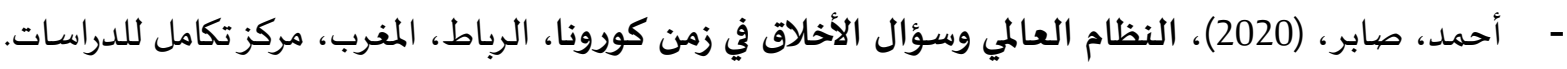
- - أنيس، إبراهيم، (2004)، المعجم الوسيط، القاهرة، المجام، مجمع اللغة العربية.

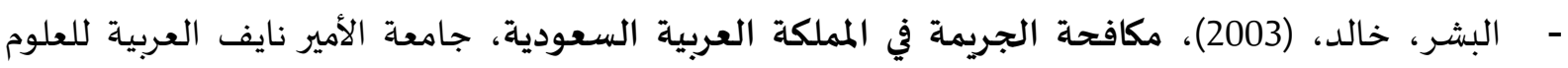
الأمنية، الرياض، السعودية.

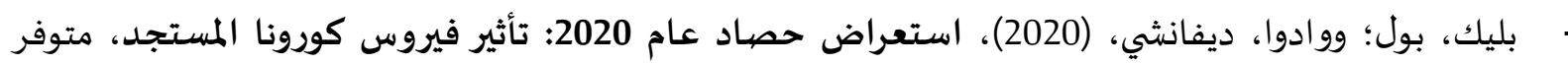

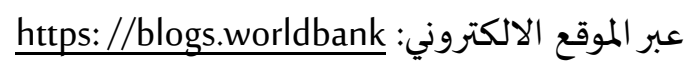
بو خميس، بوفوله، (2014)، انحراف الأحداث من منظور قيمي أخلاقي، الإسكندرية، المكتب الجامعي الحديث. بومدين، سنوسي؛ وجلولي، زينب، (2020)، الصحة النفسية في ظل انتشار فيروس كورونا كوفيد-19 والتباعد

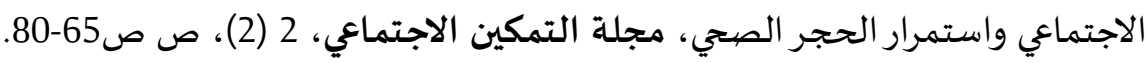

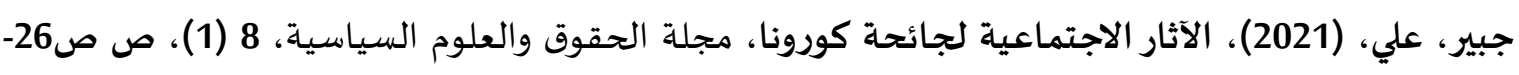


جعفر، علي، (2004)، حماية الأحداث المخالفين للقانون والمعرضين لخطر الانحراف: دراسة مقارنة،

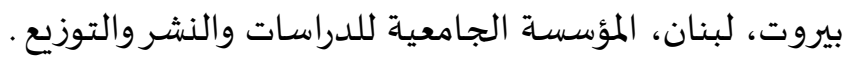

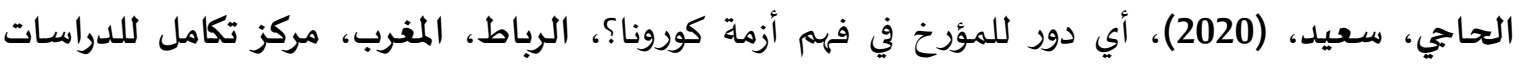
والأبحاث.

حسين، علي؛ والزهرة، حسين، (2011)، التوافق النفسي والاجتماعي وعلاقته بتقدير الذات لدى طلبة كلية

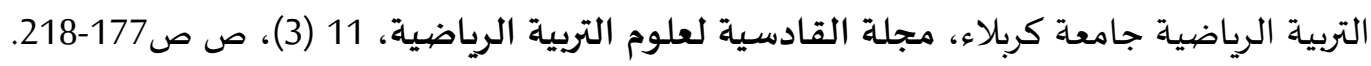

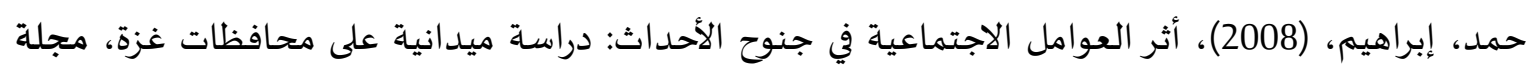

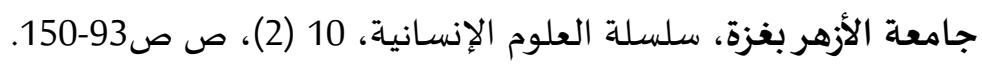

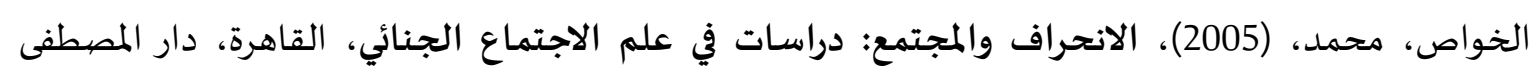
للطباعة والنشر. دريدي، فوزي، (2007)، العنف لدى التلاميذ في المدارس الثانوية الجزائرية، مركز الدراسات والبحوث، جامعة نايف العربية للعلوم الأمنية، الرياض.

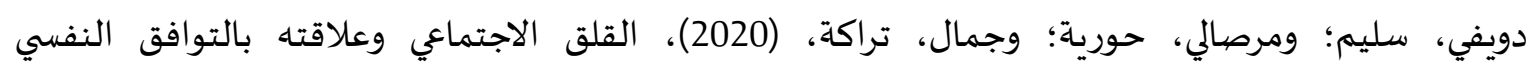
والاجتماعي لدى طلبة جامعة البليدة 2 في ظل جائحة كورونا والحجر الصيحي، مجلة التمكين الاجتماعي، 2 (2)، ص

راشـ، حمية؛ وجمال، تقيق، وقدور، إبراهيم، (2020)، إسهام النشاط الترويجي في تحقيق الأمن النفسي خلال

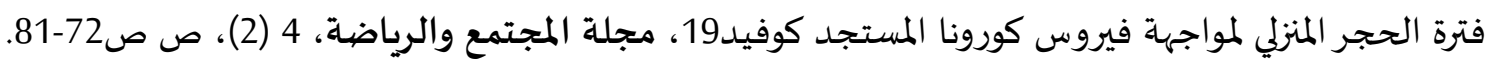

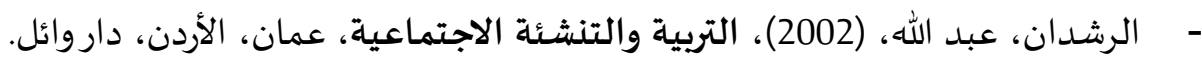
الرواضية، صالح، (2017)، أنماط التنشئة الأسرية لدى الطلبة العمانيين في جامعة مؤتة بالأردن وعلاقتها

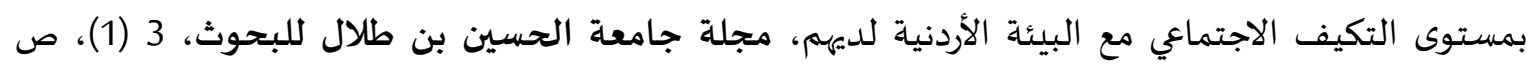
ص138-135. الرويلي، علي، (2011)، إدارة الأزمات: تعريفها، أبعادها، أسبابها، الرياض، جامعة الأمير نايف.

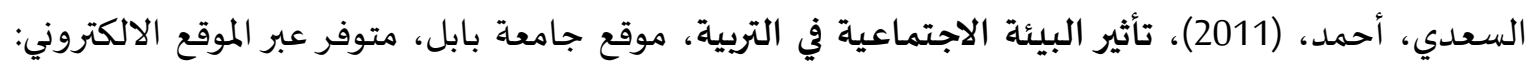
http://www.uobabylon.edu.iq السميران، ثامر؛ والمساعيد، عبد الكريم، (2014)، سيكولوجية الضغوط النفسية وأساليب التعامل معها، عمان، الأردن، دار الحامد للنشر والتوزيع. سنوسي، بومدين؛ وجلولي، زينب، (2020)، الصحة النفسية في ظل انتشار فيروس كورونا كوفيد - 19 والتباعد التهاء

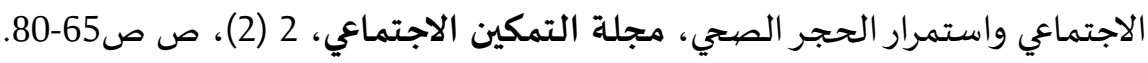

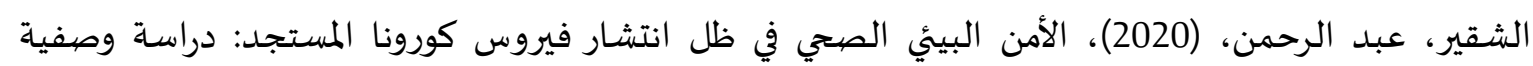
تحبليلية لبعض الممارسات الصحية في المملكة العربية السعودية، المجلة العربية للدراسات الأمنية، 36 (2)،

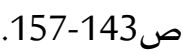
شنو، باسم، (2010). البيئة الاقتصادية والسياسية ومنعكساتها على التسوق الدولي، دمشق، جامعة دمشق. الضلاعين، نرجس، (2016)، الضغوط النفسية لدى طلبة المرحلة الثانوية وعلاقتها بالأفكار اللاعقلانية لديهم، رسالة ماجستير غير منشورة، جامعة مؤتة، الكرك، الأردن. 
- الطريري، عبد الرحمن، (2004)، الضغط النفسي لدى بعض الموظفين، مجلة المنظمة العربية للتربية والثقافة

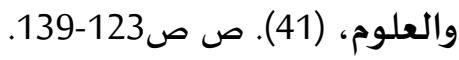

العابد، هناء، (2010)، التنشئة الاجتماعية ودورها في نمو التفكير الإبداعي لدى الشباب السوري، رسالة دكتوراه غير منشورة، جامعة دمشق، سوريا

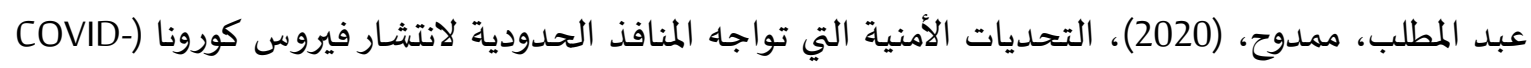

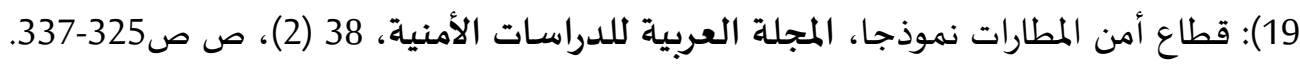

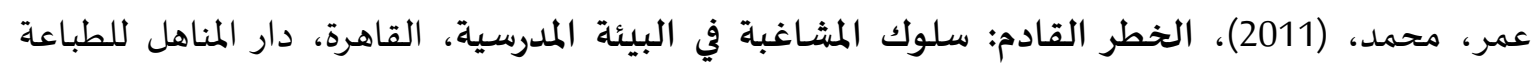
والنشر. العيسوي، عبد الرحمن، (2001)، سيكولوجية الانحراف والجنوح والجريمة، بيروت، لبنان، دار الرتب

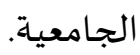
غازي، علي، (2020)، جائحة كورونا وأزمة الأخلاق، لندن، مركز للبحوث والاستشارات، المؤتمر (6) . (2020/6/8

غريب، سيد، (2006)، علم الاجتماع الحضري، القاهرة، دار المعرفة الجامعياة.

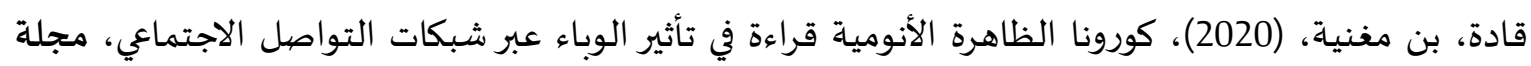

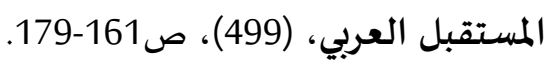
القاطرجي، منى، (2004)، الاغتصاب: دراسة تاريخية نفسية اجتماعية، بيروت، لبنان، المؤسسة الجامعية

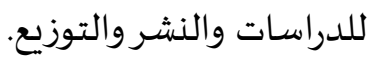
القحطاني، صالح ناصر، (2007)، الضغوط الاجتماعية وضغوط العمل وأثرها على اتخاذ القرارات الإدارية،

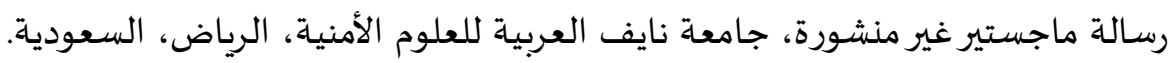

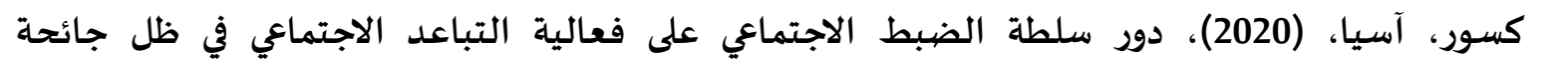

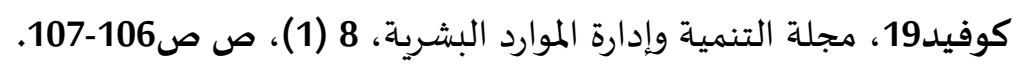

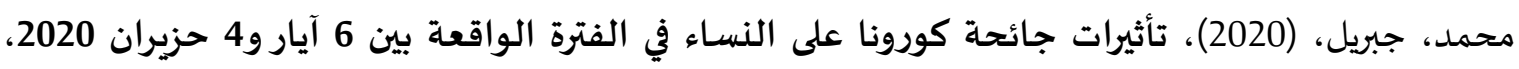
اتحاد المرأة الفلسطينية، رام الله، فلسطين.

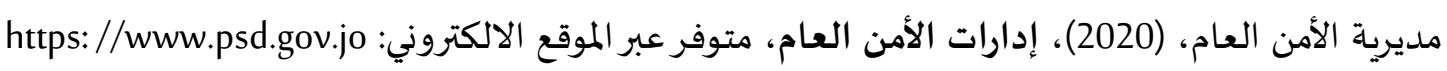

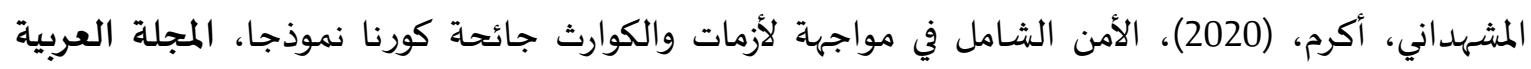

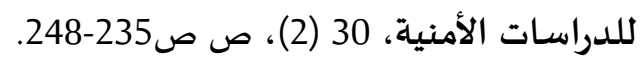
المطيري، عايش، (2010)، دور الأسرة والمدرسة في الحد من السلوك الانحرافي في مدارس منطقة الرياض بالمملكة العربية السعودية، رسالة ماجستير غير منشورة، جامعة مؤتة، الكرك، الأردن.

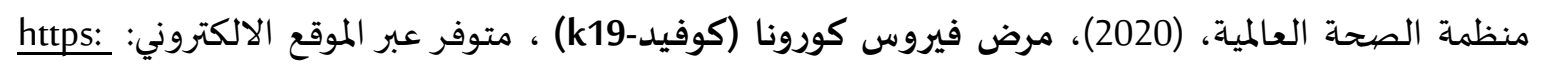
//www.who.int/ar/emergencies - الهواري، ازدهار؛ والهبارنة، نجاح، (2020)، العوامل المؤدية إلى التفكك الأسري وانحراف الأحداث في المجتمع

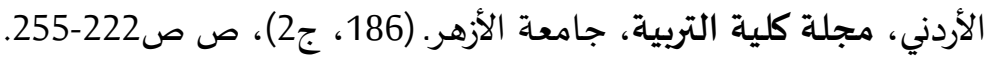

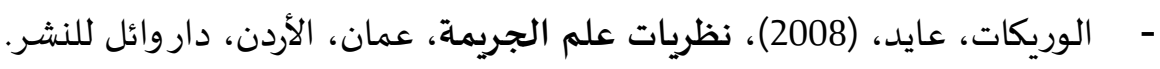



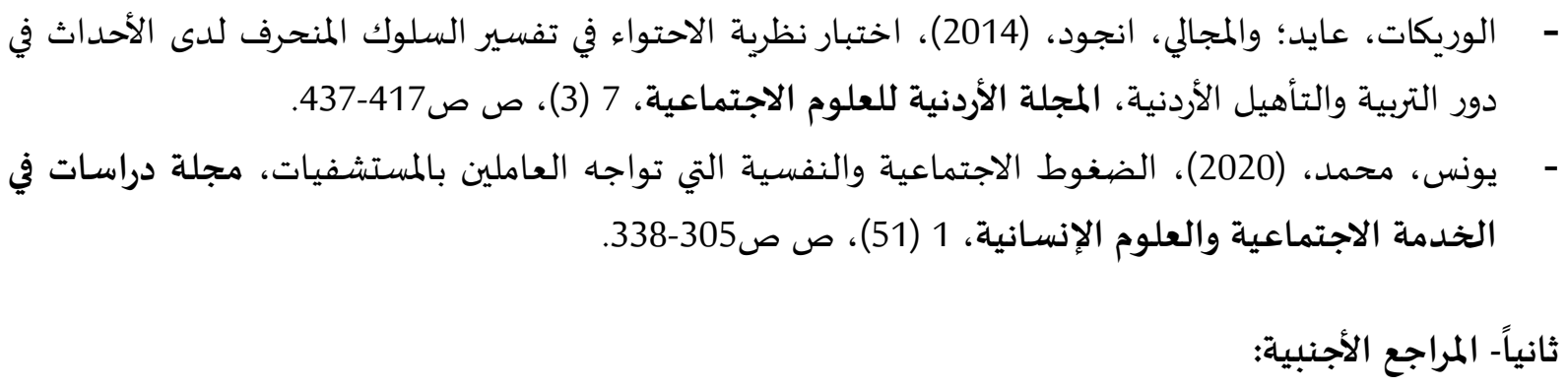

- De Vos, J. (2020). The effect of COVID-19 and subsequent social distancing on travel behavior. Transportation Research.Interdisciplinary Perspectives, 100121

- Herman; D, Gufran, D, Yahya, M, Taiyeb, M. (2015): The Community Disease Prevention Behaviors in District Maros South Sulawesi Province, International Education Studies, 8 (11), p104-112.

- Kampfa, G. Todtb, D. Pfaenderb, S. Steinmann. E. (2020): Persistence of coronaviruses on inanimate surfaces andtheir inactivation with biocidal agents, Journal of Hospital Infection, 104 (3), p 246-251.

- Kausar,R.,AbuHein,F. and Elbanna,A. (2011). Palestine adolescents, coping with stress, effect of loss of a parent and gender at adolescents, Journal of Adolescence (27), 599-610.

- Massad, I, Al-Taher, R, Massad F, Qussay, M, Haddad, M and Abufaraj, M, (2020), The impact of the COVID-19 pandemic on mental health: early quarantine-related anxiety and its correlates among Jordanians, EMHJ. Vol, 26 (10). PP 532-542

- Paschal, J. \& Ringwalt. ch. (2003). Effect of parenting father absence behavior among African American male adolescents, adolescence, (38)149. 15-20.

- Reza Shahriarirad, R \& Erfani, A\& Ranjbar, K \& Bazrafshan, A\& Mirahmadizadeh, A. (2021). The mental health impact of COVID-19 outbreak: a Nationwide Survey in Iran, https: //www.google.jo/search?q=

- Schafera, K\& Roxanne, M Schanza, G \& Anja, S. (2020). Impact of COVID-19 on Public Mental Health and the Buffering Effect of a Sense of Coherence. https://www.karger.com/Article/PDF/510752. 